\title{
Classification, Toxicity and Bioactivity of Natural Diterpenoid Alkaloids
}

\author{
Amin Mahmood Thawabteh ${ }^{1} \mathbb{D}$, Alà Thawabteh ${ }^{2}$, Filomena Lelario ${ }^{3}$, Sabino Aurelio Bufo ${ }^{3,4, * \mathbb{D}}$ \\ and Laura Scrano 5 (iD
}

1 Samih Darwazah Institute for Pharmaceutical Industries, Faculty of Pharmacy Nursing and Health Professions, Birzeit University, Bir Zeit 71939, Palestine; athawabtah@birzeit.edu

2 Medical Imaging Department, Faculty of Health Profession, Al-Quds University, Jerusalem 20002, Palestine; athawabteh@staff.alquds.edu

3 Department of Sciences, University of Basilicata, 85100 Potenza, Italy; filomena.lelario@unibas.it

4 Department of Geography, Environmental Management \& Energy Studies, University of Johannesburg, Johannesburg 2092, South Africa

5 Department of European Cultures (DICEM), University of Basilicata, 75100 Matera, Italy; laura.scrano@unibas.it

* Correspondence: sabino.bufo@gmail.com

check for updates

Citation: Thawabteh, A.M.; Thawabteh, A.; Lelario, F.; Bufo, S.A.; Scrano, L. Classification, Toxicity and Bioactivity of Natural Diterpenoid Alkaloids. Molecules 2021, 26, 4103. https: / / doi.org/10.3390/ molecules26134103

Academic Editors: Dezső Csupor, Fang-Rong Chang, Mohamed El-Shazly and John C. D'Auria

Received: 14 April 2021

Accepted: 2 July 2021

Published: 5 July 2021

Publisher's Note: MDPI stays neutral with regard to jurisdictional claims in published maps and institutional affiliations.

Copyright: (c) 2021 by the authors. Licensee MDPI, Basel, Switzerland. This article is an open access article distributed under the terms and conditions of the Creative Commons Attribution (CC BY) license (https:/ / creativecommons.org/licenses/by/ $4.0 /)$.

\begin{abstract}
Diterpenoid alkaloids are natural compounds having complex structural features with many stereo-centres originating from the amination of natural tetracyclic diterpenes and produced primarily from plants in the Aconitum, Delphinium, Consolida genera. Corals, Xenia, Okinawan/Clavularia, Alcyonacea (soft corals) and marine sponges are rich sources of diterpenoids, despite the difficulty to access them and the lack of availability. Researchers have long been concerned with the potential beneficial or harmful effects of diterpenoid alkaloids due to their structural complexity, which accounts for their use as pharmaceuticals as well as their lousy reputation as toxic substances. Compounds belonging to this unique and fascinating family of natural products exhibit a broad spectrum of biological activities. Some of these compounds are on the list of clinical drugs, while others act as incredibly potent neurotoxins. Despite numerous attempts to prepare synthetic products, this review only introduces the natural diterpenoid alkaloids, describing 'compounds' structures and classifications and their toxicity and bioactivity. The purpose of the review is to highlight some existing relationships between the presence of substituents in the structure of such molecules and their recognised bioactivity.
\end{abstract}

Keywords: diterpenoid alkaloids; Aconitum; Delphinium; Consolida; structural substituents; marine sponges; bioactivity; toxicity

\section{Introduction}

Diterpenoid alkaloids (DAs) are substances produced by various natural plants with significant thematic difficulties, bioactivity, and somewhat disreputable toxicity. To date, 1500 and more DAs have been isolated and characterised. Many remarkable DAs demonstrate different pharmacological properties such as neurotropic, antimicrobial, antitumour, hypotensive, analgesic, anti-inflammatory, muscle relaxant, antiarrhythmic, and local anaesthetic [1-8].

DAs extracted from some plants belonging to the Ranunculaceae family, especially genera Delphinium, Aconitum and Consolida, are often distinctive and recognised as cytotoxic against cancer [9]. Aconitum spp. (monkshood) is one of the most extracted and isolated sources of DAs, where more than half of natural DAs were isolated from [10-15].

DAs have long been used all over the world. People extract Aconitum due to either medicinal and beneficial properties or toxic and harmful ones. In the ancient past, Aconitum seasoned the top of arrows used for hunting animals and in wars. Of note, a Chinese tribe 
discovered that extracted crystallised Aconitum turned into a sand-like substance when left for some time [16-19].

The first DA was isolated by Geiger in the early nineteenth century when he isolated aconitine from Aconitum napellus. Then followed growing success in isolating many other DAs with simultaneous development of extraction methods, purification techniques and molecular identification, favouring their widespread use in medicine and scientific research $[1,3,7,9]$.

In the last ten years, we can acknowledge significant progress in studying DAs' phytochemistry and identifying new natural DAs. Numerous researches performed are the nourishment of many scientific articles and reviews on phytochemistry, chemical reactions, compositional and botanical studies, and 'DAs' biological activities, classifying these substances as structures containing either 18 or 19 and 20 cycled carbon atoms $\left(C_{18}\right.$, $\mathrm{C}_{19}, \mathrm{C}_{20}$ ), i.e., according to the number of contiguous carbon atoms that constitute their central arrangement $[20,21]$.

The purpose of this review is to highlight some existing relationships between the presence of substituents in the structure of such molecules and their recognised bioactivity. Structure-activity relationship (SAR) analysis can guide researchers to modify existing natural molecules or synthesise new compounds to propose novel-effective drugs. Furthermore, for comparison with plant extracted DAs, a section of this review highlights the structure of marine-diterpenoids, most of which are not alkaloids but, mainly used in alternative medicine, having received significant attention by researchers in the last decade.

\section{Classification of Diterpenoid Alkaloids}

Diterpenoid alkaloids are heterocyclic systems containing $\beta$-aminoethanol, methylamine, or ethylamine nitrogen atoms derived from the amination of tetra- or pentacyclic diterpenoids and classified into $\mathrm{C}_{18^{-}}, \mathrm{C}_{19^{-}}$, and $\mathrm{C}_{20}$-diterpenoid alkaloids, according to their carbon skeleton configuration [7].

\section{1. $C_{18}$-Diterpenoid Alkaloids}

These compounds, for a long time structurally classified as belonging to the broad group of $\mathrm{C}_{19}$-diterpenoid alkaloids, are currently considered independent. Furthermore, they are split into two distinct types: the ranaconitine-type and the lappaconitine-type. The main difference between them is the presence of additional oxygenation on the $\mathrm{C} 7$ position in the ranaconitine-type.

\subsubsection{Ranaconitine Group}

The majority of this class of compounds comes from Aconitum plants and others from Delphinium. In this class, alkaloid compounds having an oxygen group functionality in C7 comprise more than ten new compounds (structures 1-14 in Figure 1) [5-8].

Compounds 1-6 contain a 7,8-methylenedioxy group, while compounds 1, 3-6 feature a 10-OH. In particular, alkaloids 1-2 have a $16-\mathrm{OH}$ group instead of the O-methyl unit, usual in $\mathrm{C}_{18}$-DAs [22-26].

The bi-hydroxyl groups distinguish the compounds (7-12) in C8 and C7 [27]. Compound 9-puberumine-is the first example of a naturally occurring DA containing the chlorine substitute on C3 [27].

On the other hand, compound $\mathbf{1 0}$ in Figure 1 has a double bond in C2-C3, which distinguishes it from the rest of the group, and vaginatunine (11, in Figure 1) shows the presence of a methoxy substitute in C8 [28].

Alkaloids 13 and 14 in Figure 1 have an N-acetylanthranoyloxy substituent in C17; furthermore, they have fewer ester groups, suggesting that they are less toxic [29]. 


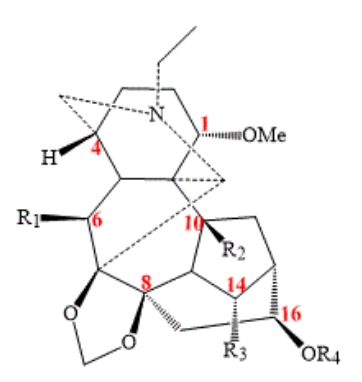

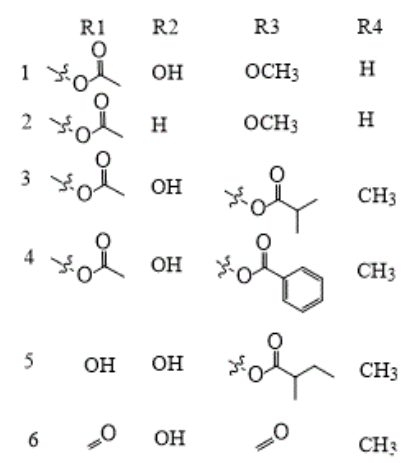
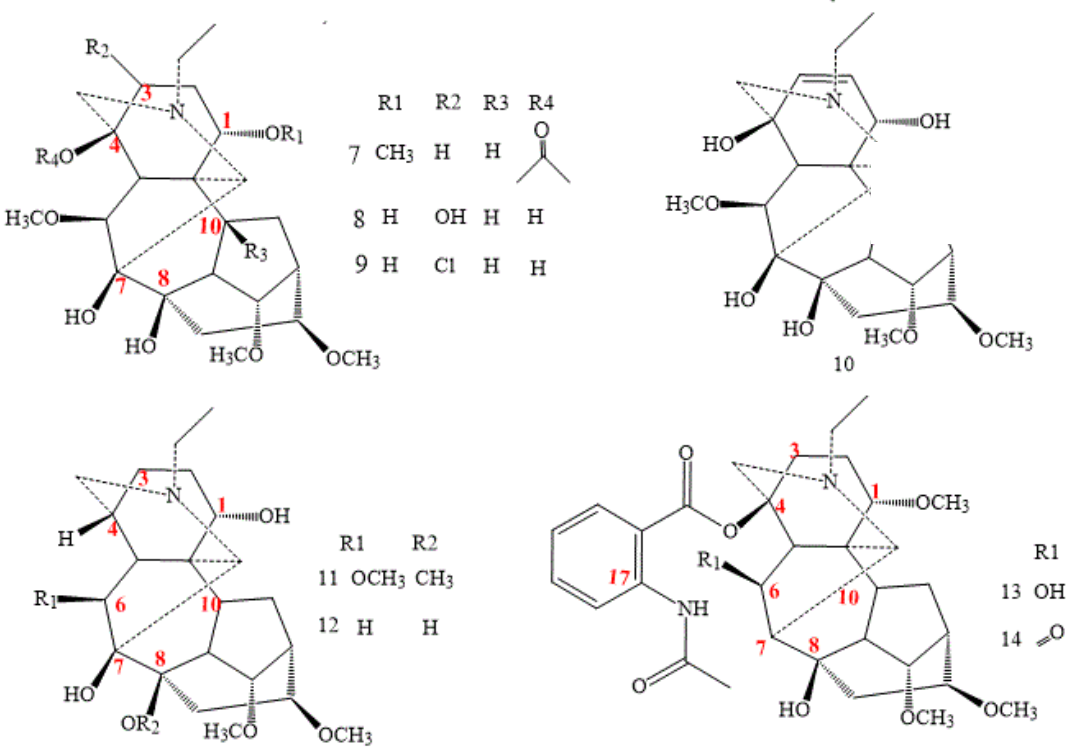

Figure 1. $\mathrm{C}_{18}$-ranaconitine Das.

\subsubsection{Lappaconitine Group}

The methine unit in C7 characterises the lappaconitine compounds; examples are natural to various Aconitum and Delphinium species [5,8].

Minor toxicity characterises plant roots containing weisaconitine compounds (structures 15-18 in Figure 2) [30]. Structurally, the lactam carbonyl and acetoxy groups are specific to weisaconitine compounds 16 and 17, respectively. Furthermore, a chlorosubstitution in $\mathrm{C} 4$ and two hydroxyl groups in $\mathrm{C} 1$ and $\mathrm{C} 3$ are natural to sinomontanine $\mathrm{N}$ (18) [31].
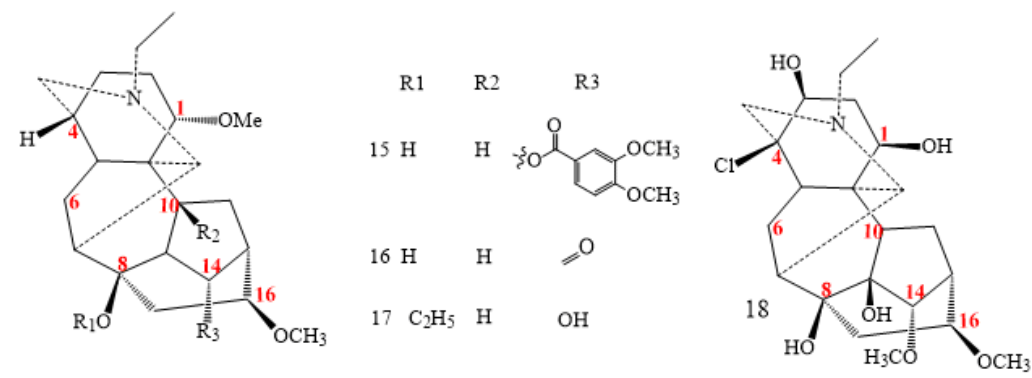

Figure 2. $\mathrm{C}_{18}$-lappaconitine DAs.

\subsubsection{Rearranged Group}

Sinomontadine (19 in Figure 3), isolated from Aconitum sinomontanum, shows a surpassing skeleton unlike other DAs compounds; it exhibits a seven-membered ring [31] instead of six, by the incorporation of a carbon atom into the six-ring system with the 
expansion to a seven carbons ring. The result is a set of new compounds such as puberudine (20, Figure 3) and puberunine (21, Figure 3), isolated from Aconitum barbatum var. puberulum and recognised as an exceptional class of DAs [27].

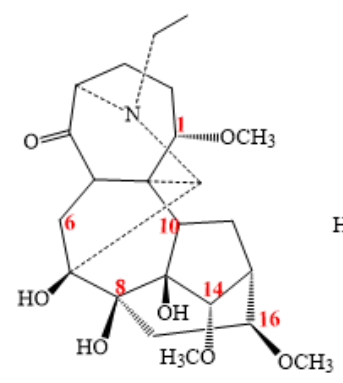

19

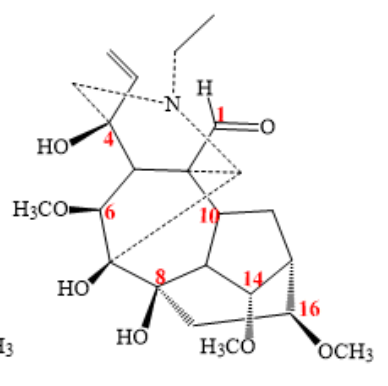

20

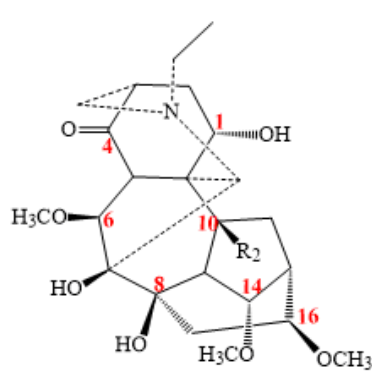

21

Figure 3. $\mathrm{C}_{18}$-rearranged DAs.

Puberudine (compound 20 in Figure 3) has a distinctive characteristic in the A ring, which is an open ring (1,2-Seco), and also a specific double bond between C2 and C3, in addition to the carbonyl group on $\mathrm{C} 1$ instead of the methoxyl or hydroxyl group [27,31].

\section{2. $C_{19}$-Diterpenoid Alkaloids}

$\mathrm{C}_{19}$ - is the largest category of the DAs, belonging to pentacyclic compounds. Most of the $\mathrm{C}_{19}$-DAs are isolated from Aconitum, Delphinium, and the roots of Aconitum carmichaelii [9].

$\mathrm{C}_{19}$-DAs are compounds classified into seven types (lactone, aconitine, lycoctonine, 7,17-Seco, franchetine, rearranged class, and glycosides) according to the oxygen-containing groups on C7 and the difference of skeleton as shown in Figure $4[20,21]$.

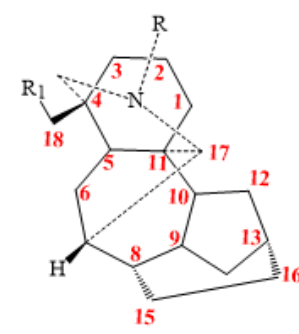

Aconitines

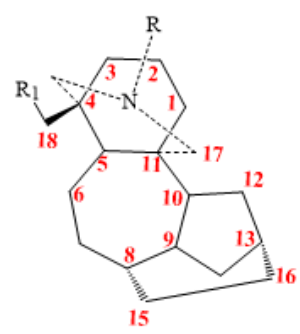

7,17-Secos

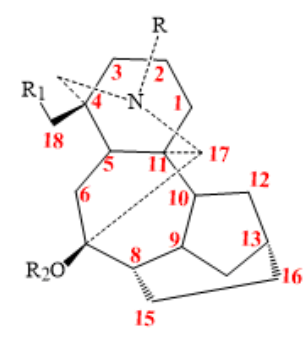

Lycoctonines

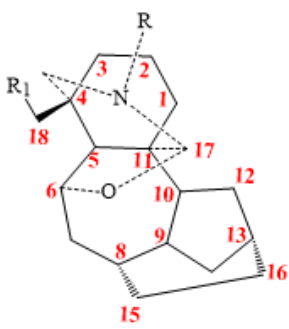

Franchetines
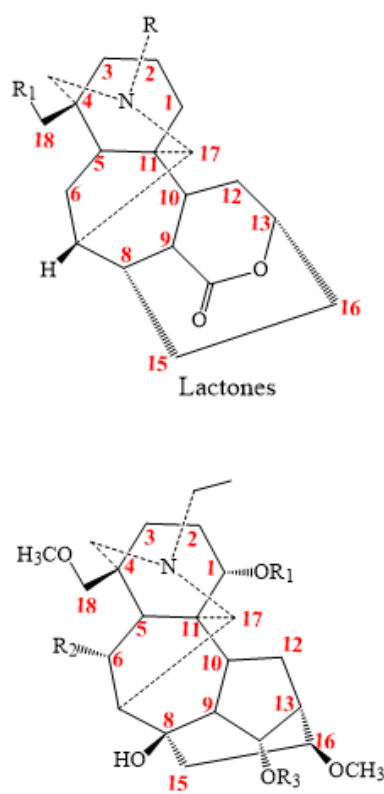

Glycosides

Figure 4. $\mathrm{C}_{19}$-DAs class.

The plurality of $\mathrm{C}_{19}$-DAs are lycoctonine and aconitine types, which are isolated from Delphinium. The presence of the oxygen-substituent group in the lycoctonine-type on C7 constitutes the difference between them. 


\subsection{1. $\mathrm{C}_{19}$-Aconitine Class}

Aconitines (structures 22-62 in Figure 5a,b) do not show an oxygenated C7. Due to the ester-group presence on $\mathrm{C} 8$ and sometimes on C14, they exhibit acute toxicity $[1,3,8]$. Several aconitines lack oxygenated groups on C15 and C6 (22-40) and rarely arrange a hydroxyl group on $\mathrm{C} 1$ as compound 22 [2,3,32-50].

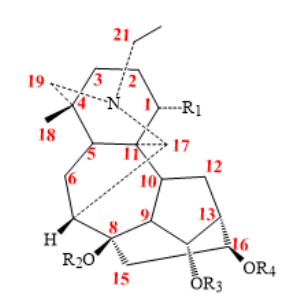

$22-25$

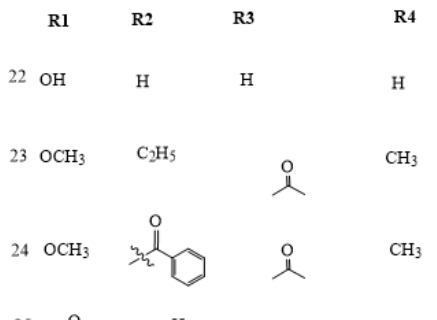

$250 \mathrm{H} \quad \mathrm{H} \quad \mathrm{CH}_{3}$

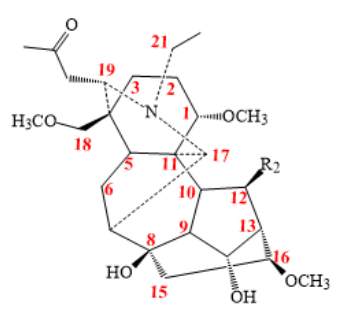

30

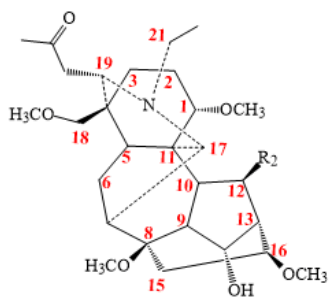

31

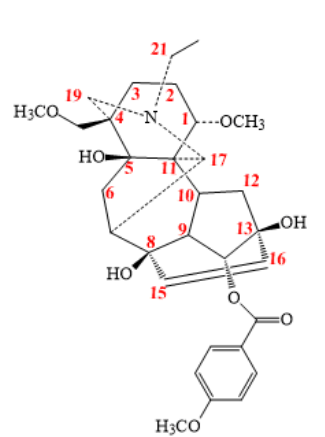

32

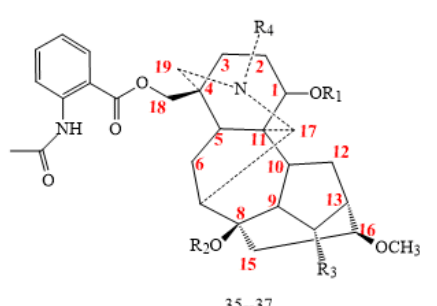

$35-37$

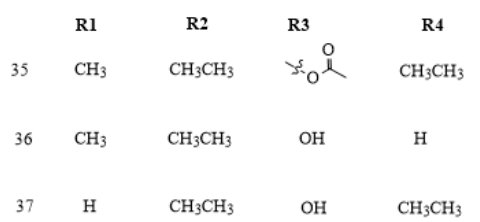

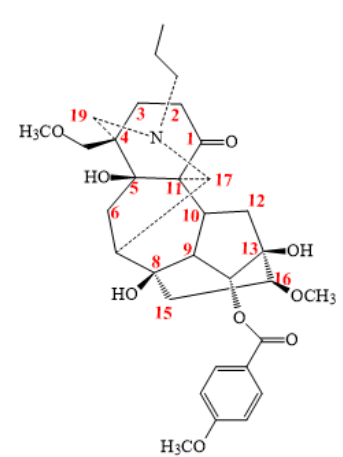

33

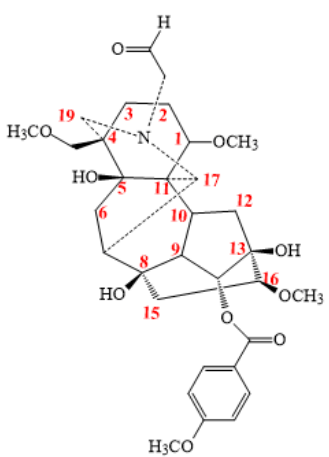

34

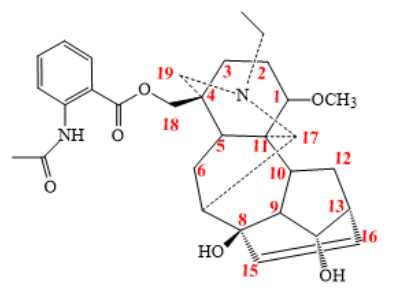

38

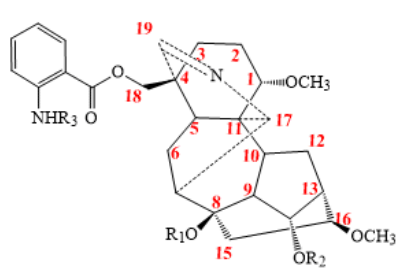

$39-40$

$\begin{array}{cccc} & \mathbf{R 1} & \mathbf{R 2} & \text { R3 } \\ 39 & \mathrm{CH}_{3} \mathrm{CH}_{3} & \mathrm{H} & \text { 3. } \\ 40 & \mathrm{H} & \mathrm{CH}_{3} & \mathrm{H}\end{array}$

(a)

Figure 5. Cont. 


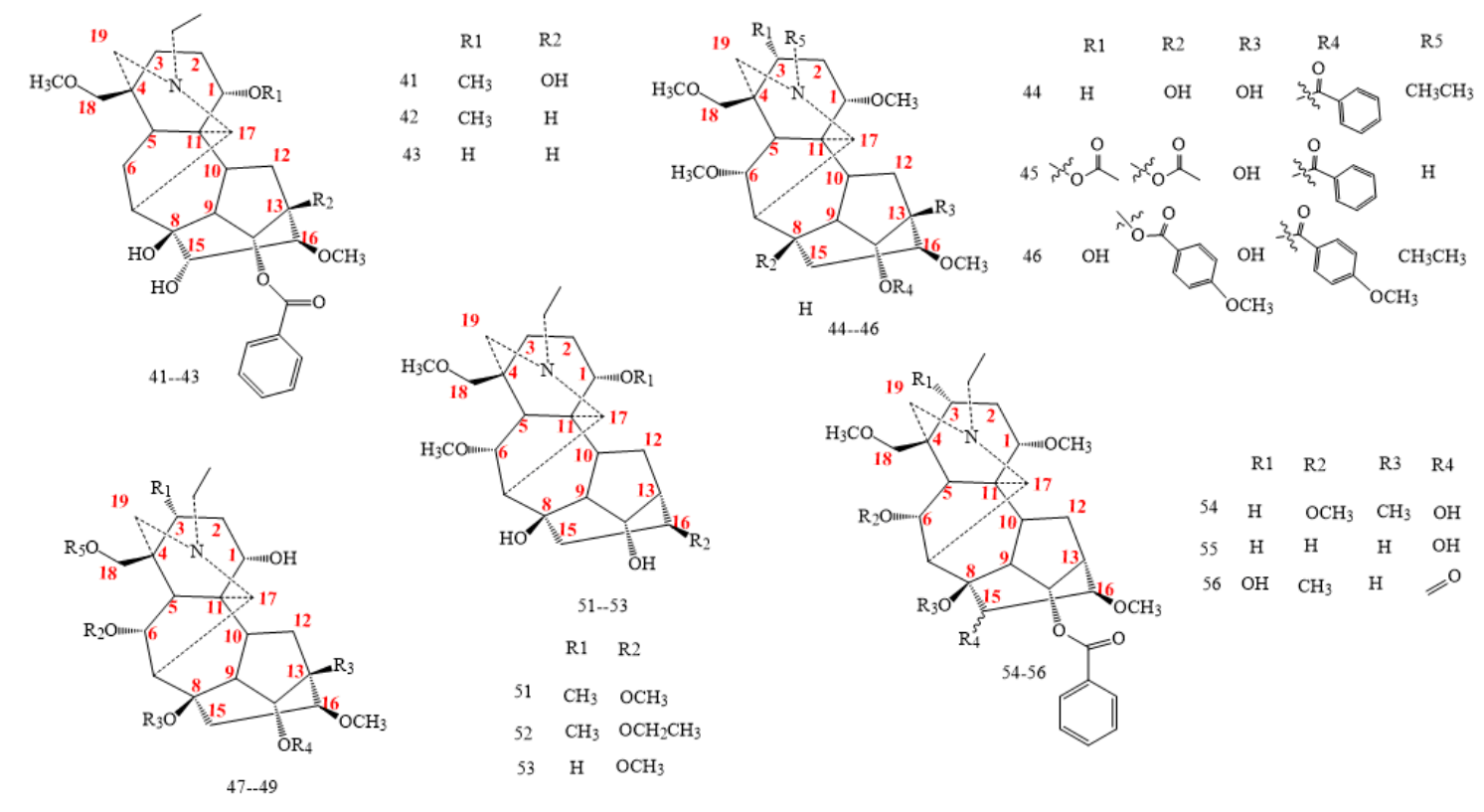

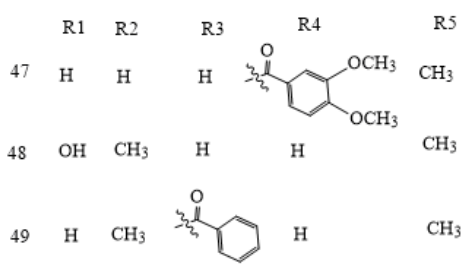

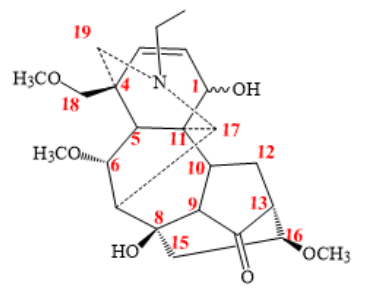

$50 \mathrm{~A}$

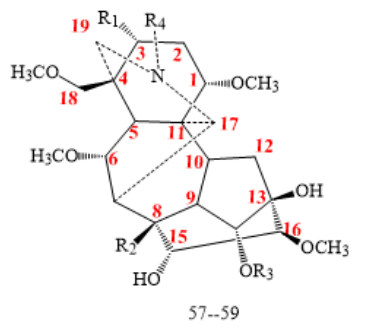

58

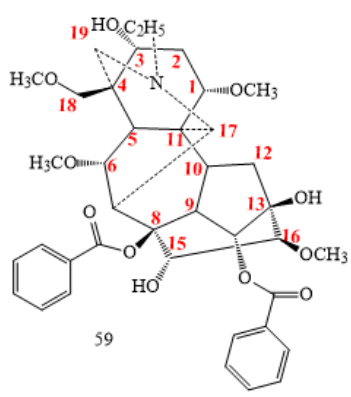

$$
\begin{array}{lll} 
& \mathrm{R} 1 & \mathrm{R} 2 \\
61 & \mathrm{CH}_{3} & \mathrm{H} \\
62 & \mathrm{C}_{4} \mathrm{H}_{10} & \mathrm{OH}
\end{array}
$$

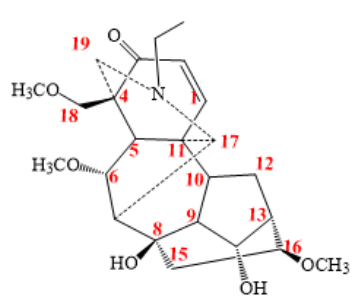

$50 \mathrm{~B}$
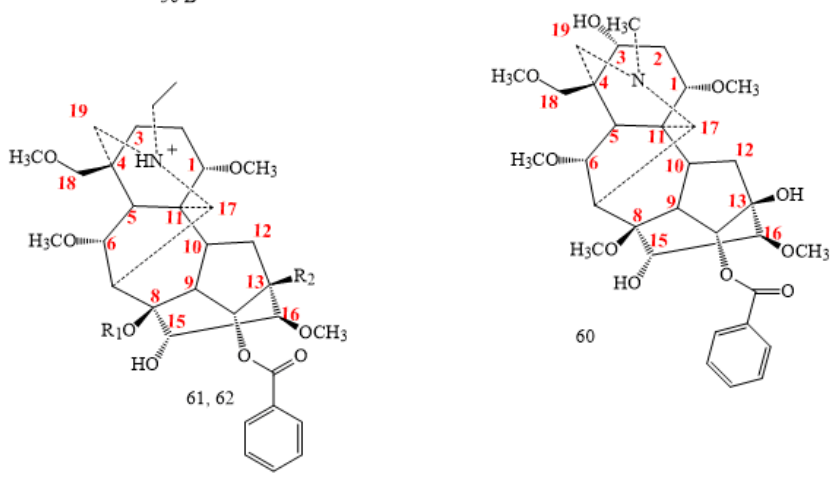

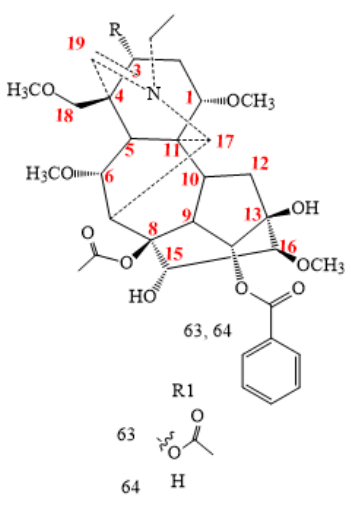

(b)

Figure 5. (a) $\mathrm{C}_{19}$-aconitine Das, structures 22-40. (b) $\mathrm{C}_{19}$-aconitine Das, structures 41-62. 
Some aconitine compounds (26-29, in Figure 5a) display a double bond between C19 and $\mathrm{N}$, which isolate from Aconitum hemsleyanum var. circinatum and Aconitum straminifiorum. Others bear an additional $\mathrm{CH}_{2} \mathrm{COCH}_{3}$ group on $\mathrm{C} 19$, with the same skeleton as acetonyl-talatisamine (30, Figure 5a) and hemaconitine D (31, Figure 5a) [41,42,51].

Three new $\mathrm{C}_{19}$-DA compounds, isolated from the genus Aconitum (32-34), distinguish an anisoyl group in C14 and a double bond between $\mathrm{C} 15$ and C16, as for compound 32 . DAs 35-40 have an anthranoyl substituent in C18 and a double bond between C15 and $\mathrm{C} 16$, as is visible for compounds $\mathbf{3 8 - 4 0}$, further to the specific double bond $\mathrm{N}=\mathrm{C} 19[37,38]$. Compounds 41-43 in Figure 5b are water extract of the A. carmichaelii lateral roots. They lack the oxygenated unit in $\mathrm{C} 6$ while showing an oxygenated group in $\mathrm{C} 15$. On the contrary, other C19-DAs (44-53) have an oxygen-containing substituent in C6 and lack oxygen in C15. And some (54-64) have both oxygen-containing groups in C6 and C15 [3,32].

Furthermore, DAs 61-62, isolated from the roots of A. carmichaelii, are characterised by the presence of quaternary amine (cation) having a positive charge (+HN-3R), which tolerate a function similar to that of a nitrone $(+\mathrm{NO}=\mathrm{C})$ [52].

\subsection{2. $\mathrm{C}_{19}$-Lycoctonine Class}

The ester ratio at $\mathrm{C} 8$ or $\mathrm{C} 14$ in lycoctonines (Figure 6) is less than the ester ratio in aconitine, whereas the ratio at $\mathrm{C} 18$ is higher in the lycoctonine class. Lycoctonines are subdivide into two subtypes based on the methylenedioxy group attached at $\mathrm{C} 7$ and $\mathrm{C} 8$. Some lycoctonines, isolated from Aconitum, differentiate with diol at $\mathrm{C} 7-\mathrm{C} 8$ as compounds 63-73 in Figure 6. Other lycoctonines characterise the presence of 7,8 methylenedioxy group (74-81), as shown in Figure 6 [22,53-63].
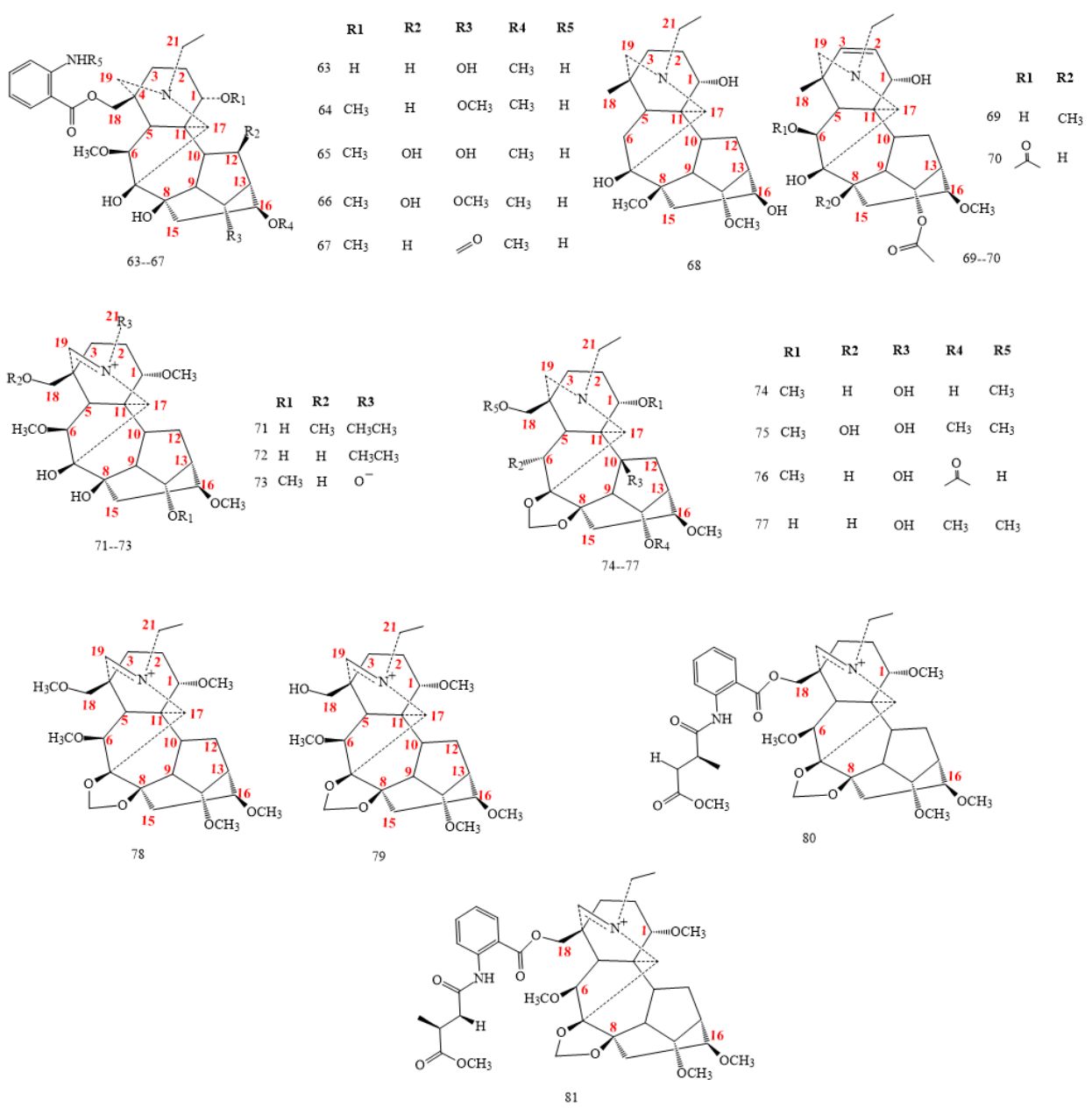

Figure 6. $\mathrm{C}_{19}$-lycoctonine DAs. 
DAs 63-67 in Figure 6 show an O-acetamidobenzoate moiety [54-57]. DAs 65 and 66 exhibit hydroxyl substitution at C12 [54]. Tianshanitine B (68) has hydroxyl instead of methoxy in C16. Anthriscifoldine A (69) and majusine C (70) exhibit a double bond between C2 and C3 [22,56,58]. A nitrone functionality is highlightable in DAs 71-73 (Figure 6) due to the $\mathrm{N}=\mathrm{C} 19$ moiety.

An unfamiliar hydroxyl group is detectable on C10 in compounds 74-77. Moreover, DAs 78-81 show a quaternary amine with the $\mathrm{N}=\mathrm{C} 19$ double bond $[63,64]$.

The known, naturally occurring alkaloids of the amine subtypes in the aconitine and lycoctonine types possess the following distinctive features:

(i) In most cases, they have oxygenated functionalities at C1, C6, C8, C14, C16, and C18. Interestingly, the positions of these oxygenated groups are specific for the resulting structural tendency from simple to complex: $\mathrm{C} 13$ or $\mathrm{C} 10$ to $\mathrm{C} 3 / \mathrm{C} 13$ or $\mathrm{C} 3 / \mathrm{C} 10$ to C3/C13/C15 or C3/C10/C13/C15 [32,50].

(ii) Many alkaloids contain only the common oxygenated groups, e.g., methoxyl and hydroxyl group(s). In most cases, the methoxyl groups locate at C1, C16, and C18. The hydroxyl groups mainly located at C8 and C14. The presence of hydroxyl groups at C3, C10, C13, and C15 may lead to their structural diversity $[53,54,63]$.

(iii) Some alkaloids contain only the common ester groups, e.g., acetoxy group and benzoyloxy. There are a few examples with other ester groups. Among them, the acetoxy group presents a chemotaxonomic characteristic. The ester groups locate at C8, C14, or C8/C14 [3,32].

(iv) They contain an N-ethyl structural unit. Very few alkaloids possess an N-methyl group [33].

(v) The oxygenated substituents at the $\mathrm{C} 1, \mathrm{C} 6$, and $\mathrm{C} 15$ positions of the alkaloids possess an a-orientation in most cases [42].

\subsection{3. $\mathrm{C}_{19}$-Lactone Class}

A six-membered lactone characterises this class (structures 82-85 in Figure 7) obtained by the oxidation of the ketone existing at C14 of aconitine (Figure 7) [65-67].
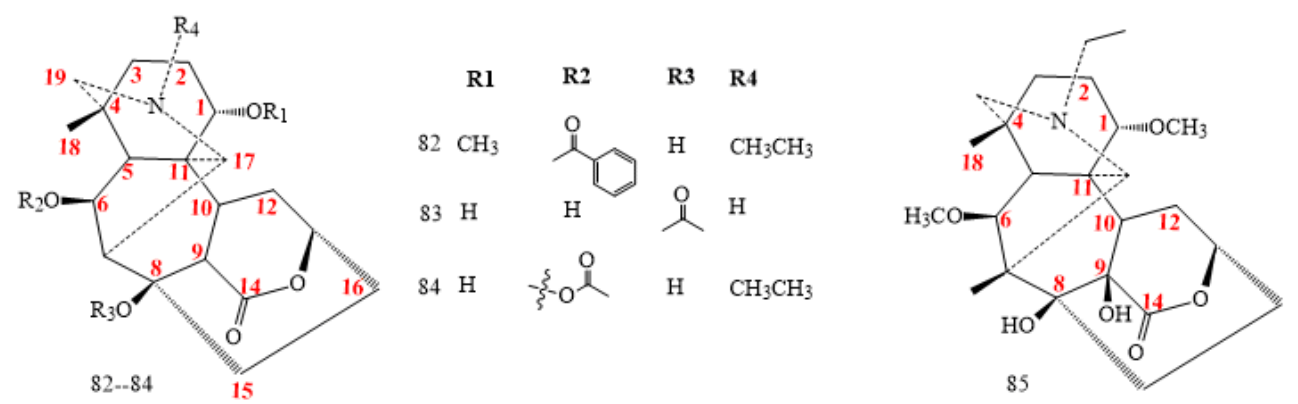

Figure 7. $\mathrm{C}_{19}$-lactone DAs.

The lactone-type $\mathrm{C}_{19}$-diterpenoid alkaloids contain simpler oxygenated functionalities as compared to the aconitine- and lycoctonine-type $\mathrm{C}_{19}$-diterpenoid alkaloids. All lactonetype $\mathrm{C}_{19}$-diterpenoid alkaloids lack oxygenated functionalities at the $\mathrm{C} 3, \mathrm{C} 7, \mathrm{C} 13$, C15, and $\mathrm{C} 16$ positions and possess oxygenated groups at the $\mathrm{C} 1$ and $\mathrm{C} 8$ positions. They also have an oxygenated functionality at the C6 position in most cases. Only a very few alkaloids have no oxygenated groups at both C6 and C16 positions [65-67].

\subsection{4. $\mathrm{C}_{19}-7,17-$ Seco Class}

7,17-Seco compounds derive from aconitine DAs with outstanding C7-C8 double bond. DAs 86-89 (Figure 8) show oxygen in C15, except for compound 89. Most of the Seco DAs class come from Aconitum brachypodum [42,68-70]. Brachyaconitine C (86) exhibits a $\mathrm{C} 17=\mathrm{N}$ unit in 7,17, while secoaconitine (88) shows an epoxy ring between C17 and C3 [69]. 

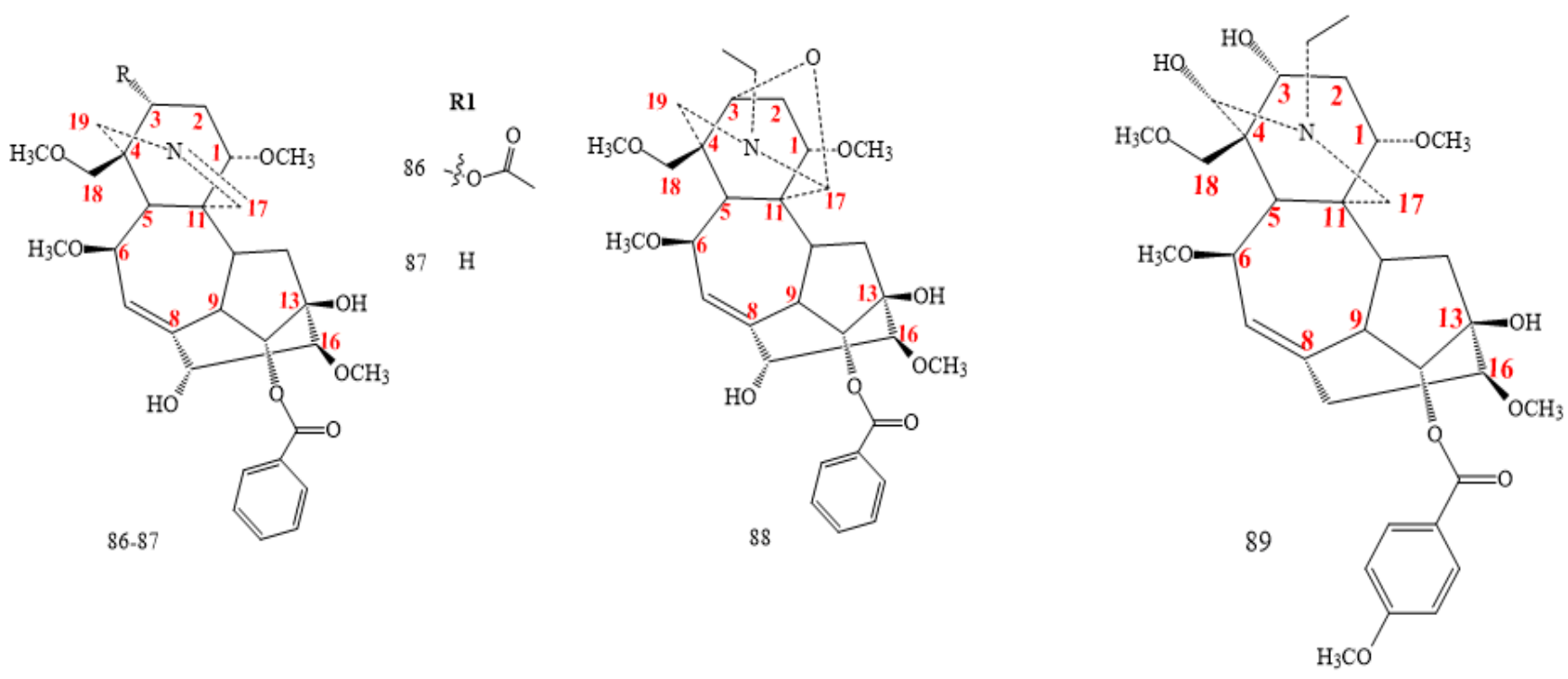

Figure 8. $\mathrm{C}_{19}$ 7,17-Seco DAs.

\subsection{5. $\mathrm{C}_{19}$-Franchetine Class}

DAs in this class (90-93 in Figure 9) feature an additional oxygenated bond between C6 and C17 [37,38,41,47,71,72]. All compounds exhibit a double bond between C7 and C8, except 92, 7,8-epoxy-franchetine from A. straminifiorum [37,38,42,71,72]. Guiwuline (structure 90 in Figure 9) is an example of a compound having an $\mathrm{OH}$ group in $\mathrm{C} 15$ [37].
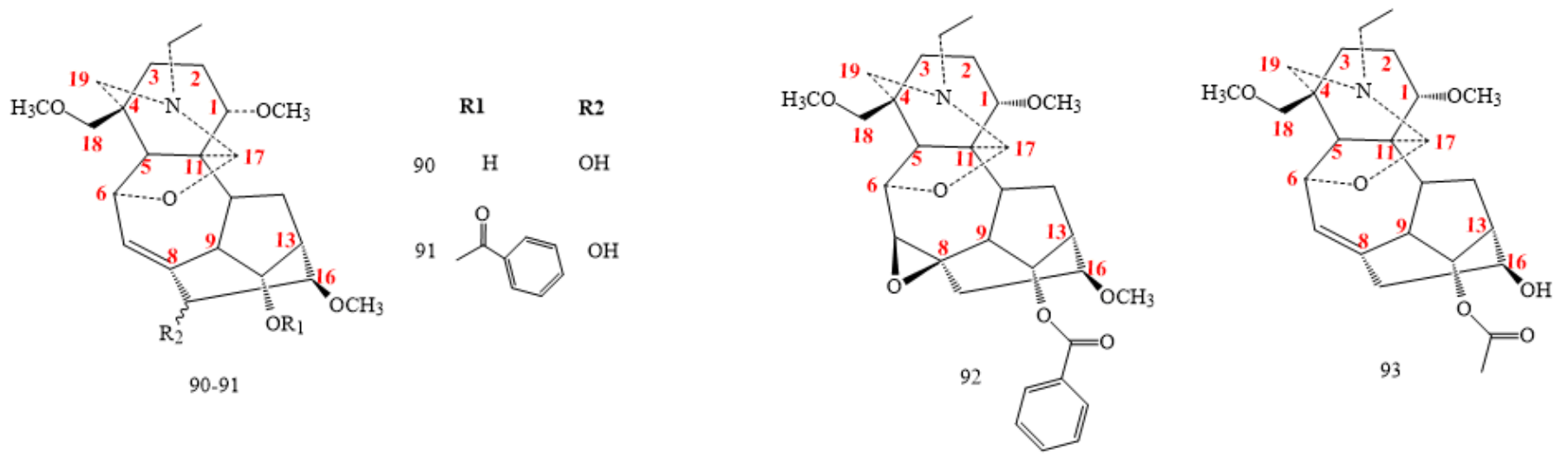

Figure 9. $C_{19}$-franchetine DAs.

\subsection{6. $\mathrm{C}_{19}$-DA Glycosides}

Aconicarmichosides A-H, K-L, and I-J (structures $\mathbf{9 4 - 1 0 0 ~ i n ~ F i g u r e ~ 1 0 ) ~ a r e ~ t h e ~ o n l y ~}$ glycosidic DAs found in nature $[20,21]$. Structurally, they belong to the aconitine class, with the addition of the sugar moieties, and include L-arap and L-araf in C1 or C14 [5-8]. These compounds are currently components of the aqueous extract from A. carmichaelii lateral roots [5-8]. 


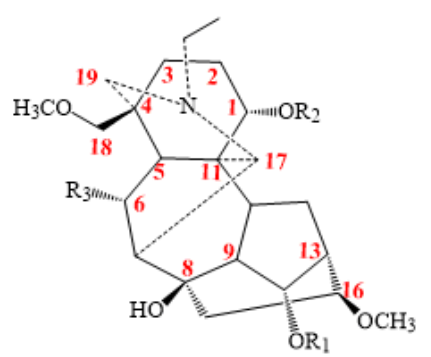

94-100

$\begin{array}{llll} & \text { R1 } & \text { R2 } & \text { R3 } \\ 94 & \text { ALP } & \text { H } & \text { H } \\ 95 & \text { ALF } & \text { H } & \text { H } \\ 96 & \text { ALF } & \text { H } & \mathrm{OCH}_{3} \\ 97 & \text { BLF } & \text { H } & \mathrm{OCH}_{3} \\ 98 & \text { ALP } & \mathrm{CH}_{3} & \mathrm{H} \\ 99 & \text { ALP } & \mathrm{CH}_{3} & \mathrm{OCH}_{3} \\ 100 & \mathrm{H} & \mathrm{BLF} & \mathrm{OCH}_{3}\end{array}$

$\mathrm{CH}_{3}$

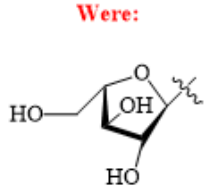

Alpha - L - Araf (ALF)

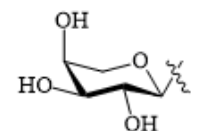

Alpha - L - Arap (ALP)

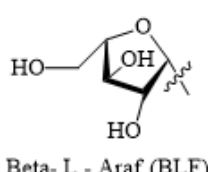

Beta- L - Araf (BLF)

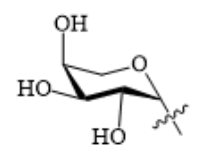

Beta- L - Arap (BLP)

Figure 10. $\mathrm{C}_{19}$-glycosides DAs.

\subsection{7. $\mathrm{C}_{19}$-DA Rearranged Class}

Puberuline $C$ and yunnanenseine A (structures 101 and 102 in Figure 11, respectively), isolated in the order from A. barbatum var. puberulum and Delphinium yunnanense, belong to the rearranged class with the $\mathrm{C} 8-\mathrm{C} 17$ bond, rather than a C7-C17 bond [73-75].

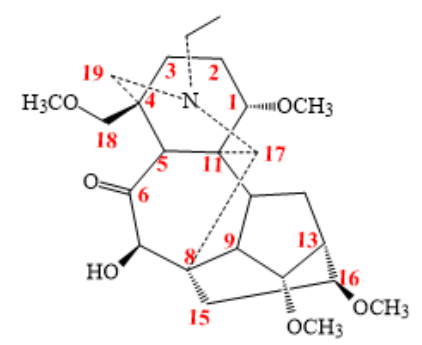

101

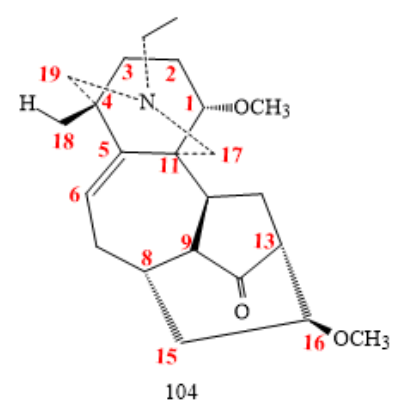

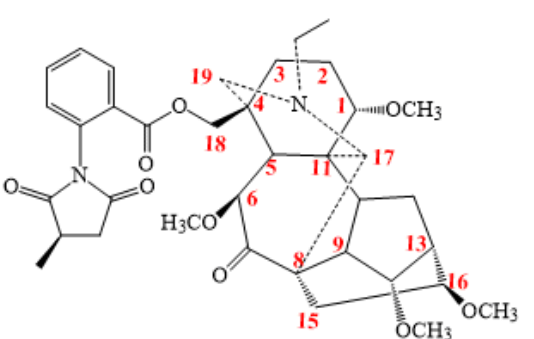

102

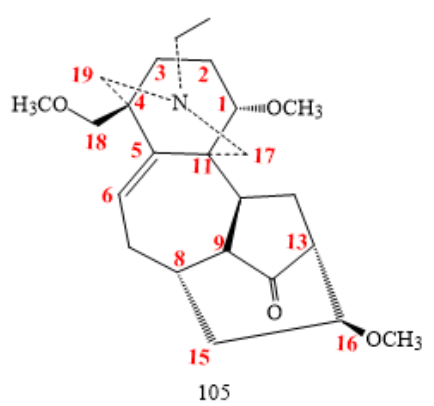

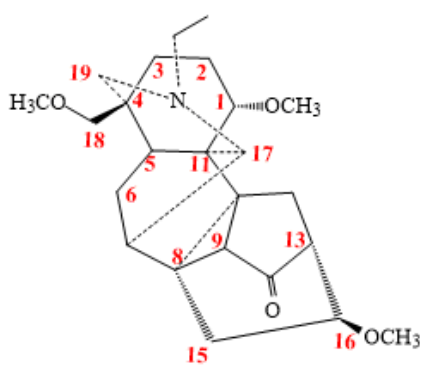

103

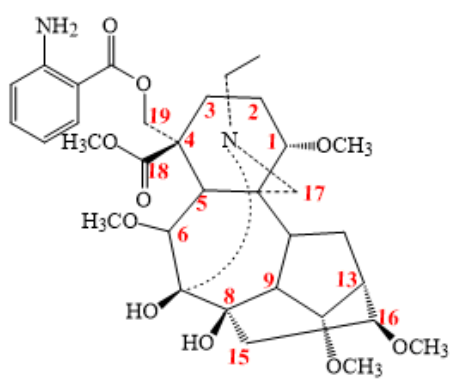

106

Figure 11. $\mathrm{C}_{19}$-rearranged DAs.

Aconitramine A (103 in Figure 11), isolated from the Aconitum transsectum, shows a three-membered ring formed via C8, C9, and C10 [32].

Hemsleyaconitines F (104 in Figure 11) and G (105 in Figure 11), typically extracted from $A$. hemsleyanum, exhibit skeletons with five-membered D-ring linking C9, C13, C14, $\mathrm{C} 15$, and $\mathrm{C} 16$, which looks different from the six-membered D-ring of their analogues [74].

Grandiflodine B (compound 106 in Figure 11) from Delphinium grandiflorum is distinctive of a remarkable skeleton with the cleavage of $\mathrm{N}-\mathrm{C} 19$ and $\mathrm{C} 7-\mathrm{C} 17$ bonds [76].

\section{3. $C_{20}$-Diterpenoid Alkaloids}

DAs- $C_{20}$ are more complex compounds than $C_{18}$ and $C_{19}$. They are tetracyclic diterpenes with a 20-carbons skeleton; a Trans ring connects between C19 and C20. Most DAs- $\mathrm{C}_{20}$ isolated from Delphinium and classified as atisine, denudatine, hetisine, hetidine, anopterine, napelline, and vakognavine (Figure 12). 


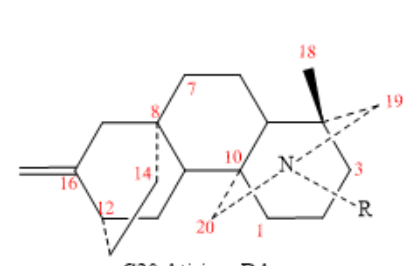

C20 Atisines DAs

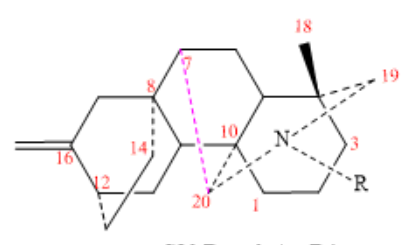

C20 Denudatine DAs

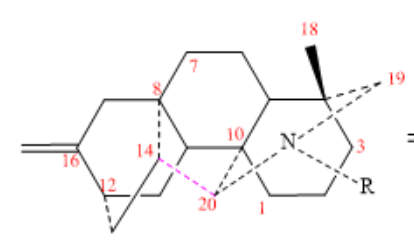

c20 Hetidine

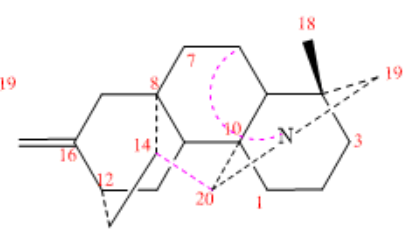

C20 Hetisine

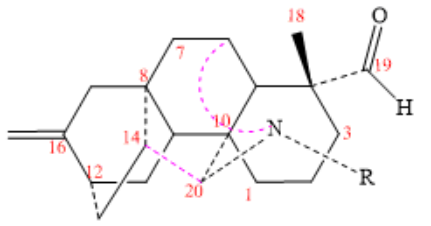

C20 Vakognavine DAs

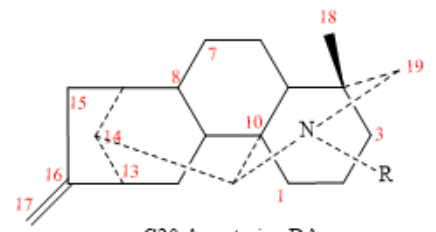

C20 Anopterine DAs

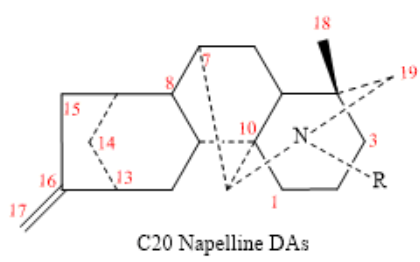

C20 Napelline DAs

Figure 12. DAs- $\mathrm{C}_{20}$ classes.

\subsection{1. $C_{20}$-Atisines Class}

Atisines are DAs isolated from different species of the genera Aconitum, Delphinium and Spiraea [7,8]. Whereas spirimines A and B (107 and 108 in Figure 13) result from Spiraea japonica var. acuminata [77]. DA-108 shows a methoxy group on C19 [77], whereas leucostomines A and B (109 and 110 in Figure 13) exhibit a quaternary ammonium hydroxyethyl group. Compounds 111-113 reveal an oxazolidine ring, and compound 112, a trimethyl-oxocyclohexyloxy group. DAs 114-116 exhibit an $\mathrm{O}-\mathrm{C}-\mathrm{N}$ unit between $\mathrm{C7}$ and $\mathrm{C}_{20}$, and structure 116 shows a carbonyl group at C15 [78-80].

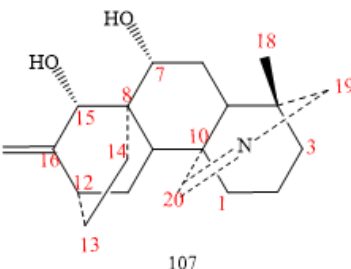

107
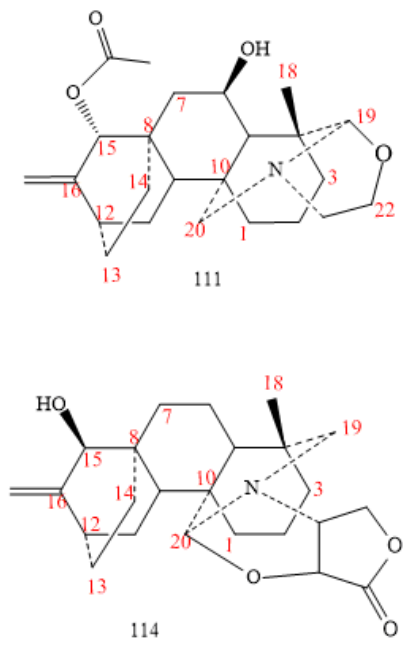
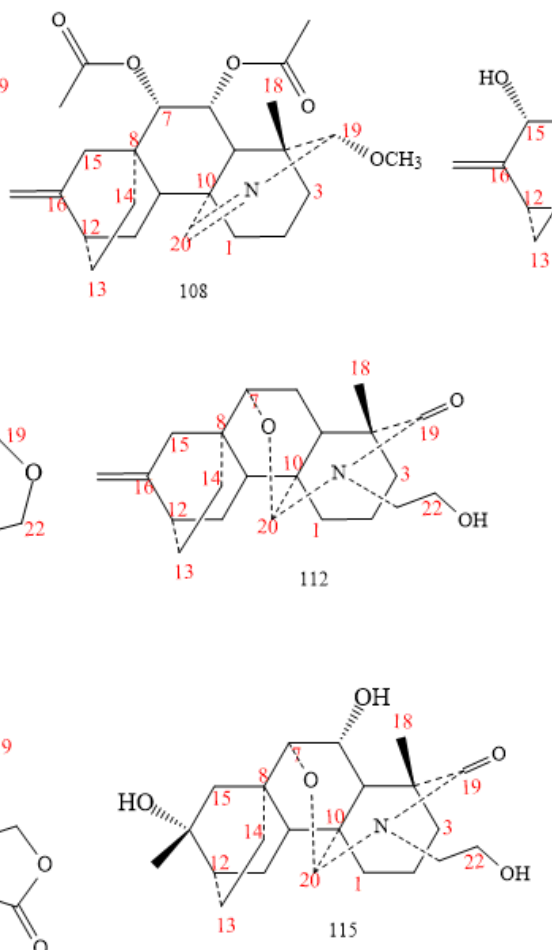
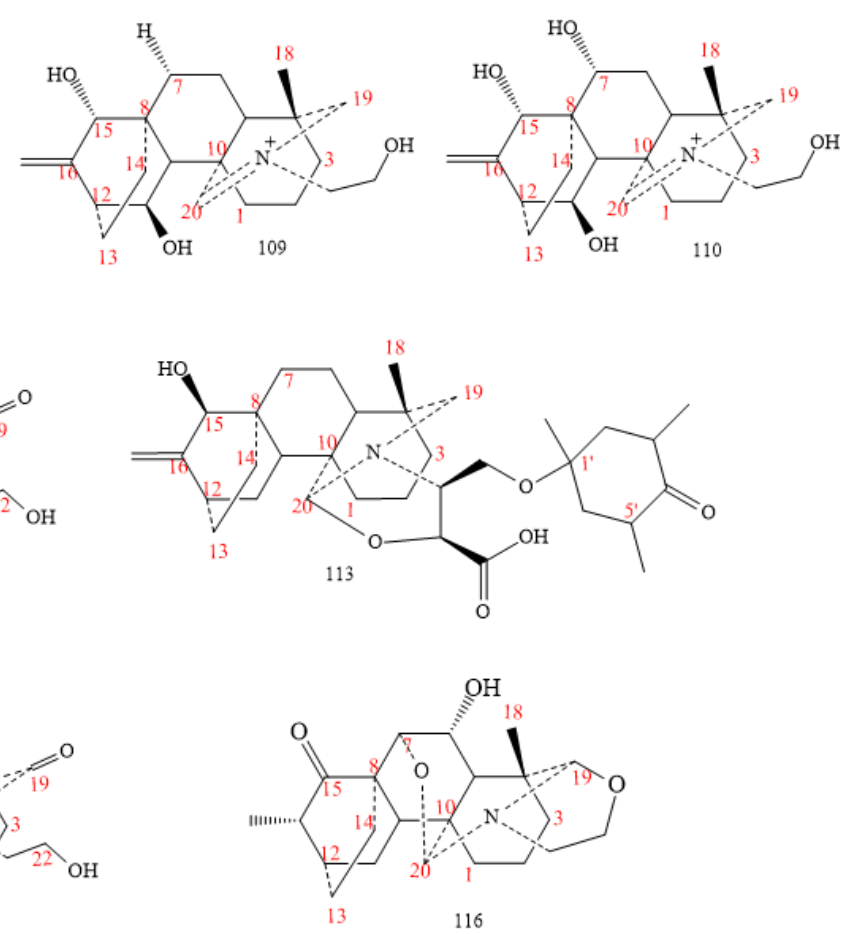

Figure 13. $\mathrm{C}_{20}$-atisines DAs.

\subsection{2. $\mathrm{C}_{20}$-Denudatine Class}

Most of the denudatine DAs (compounds 81-89 in Figure 14) originate from Aconitum spp, except DAs 123-124 obtained from the whole herb of Delphinium anthriscifolium var. savatieri [81]. A hydroxyl group and an oxygenated group are respectively on C16 and 
C17 in DAs 117-120. Finally, an epoxy group between C16 and C17 is visible in DAs 123-125 [82-91].
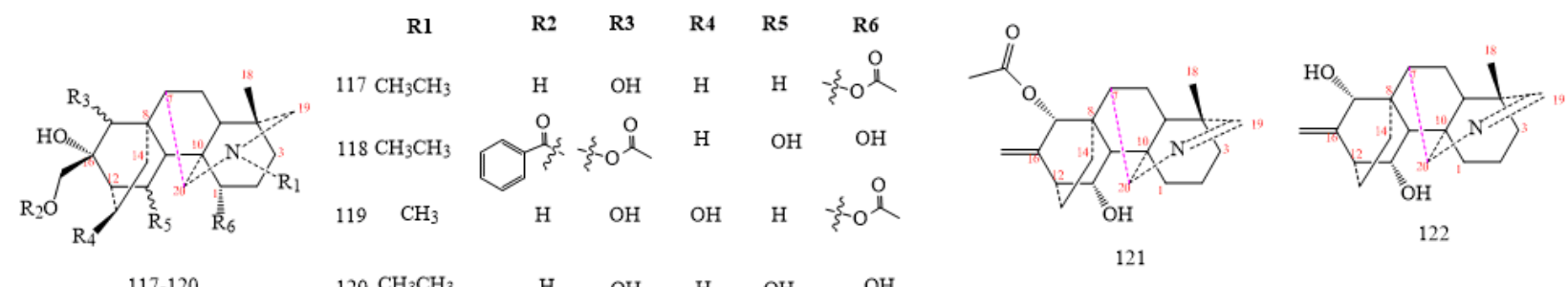

$117-120$

$120 \mathrm{CH}_{3} \mathrm{CH}_{3}$

$\mathrm{H} \quad \mathrm{OH} \quad \mathrm{H} \quad \mathrm{OH} \quad \mathrm{OH}$

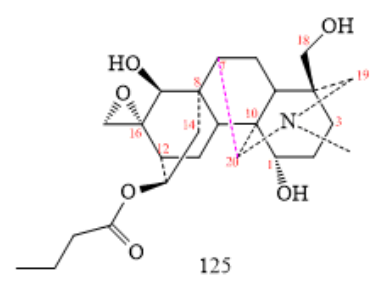

Figure 14. $C_{20}$-denudatine DAs.

\subsection{3. $\mathrm{C}_{20}$-Hetisine Class}

Hetisines are the most prominent $C_{20}$-DAs members (structures 126-138 in Figure 15). Most of them isolated from Aconitum spp. and Delphinium spp. [7,8], and include hydroxyl or methoxide groups in C6 and C3 as shown by structures 126-130 [43]. DAs 126-129 exhibit an $\mathrm{OH}$ group on $\mathrm{C} 6$, whereas compound $\mathbf{1 3 0}$ brings a methoxide. An a-oriented $\mathrm{OH}$ group at $\mathrm{C} 3$ is characteristic of most $\mathrm{C}_{20}$-DAs; however, compound 129 possesses a b-oriented $\mathrm{OH}$ group [92-94]. Propionyloxy in C13 and 2-methyl butyryloxy moieties in C2 and a quaternary $\mathrm{N}$ base characterise compounds 131-133 obtained from the lateral roots of A. carmichaelii. Compounds 134-138 lose an oxygen group in C11 and C13 [67,95-100].

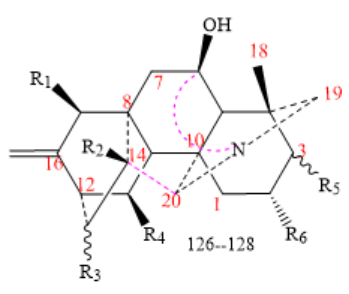

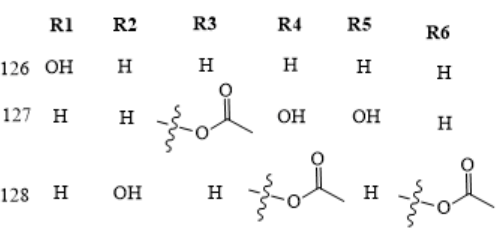

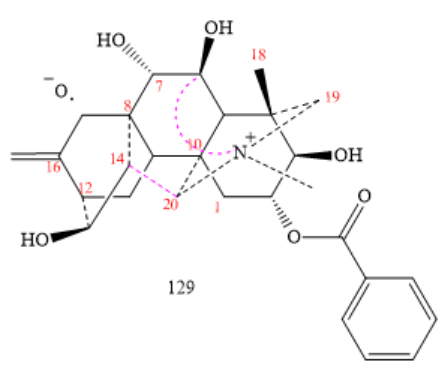

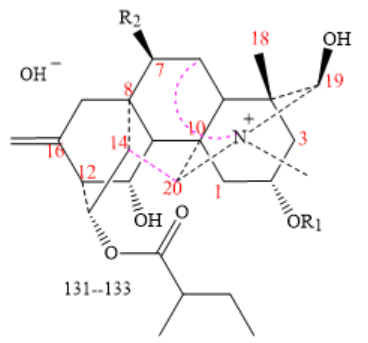
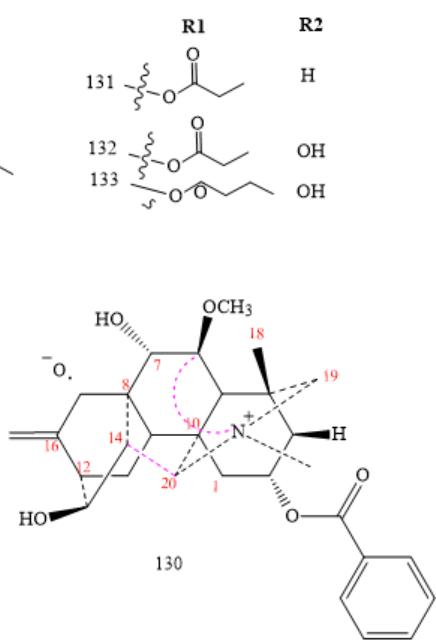

Figure 15. $\mathrm{C}_{20}$-hetisine DAs.

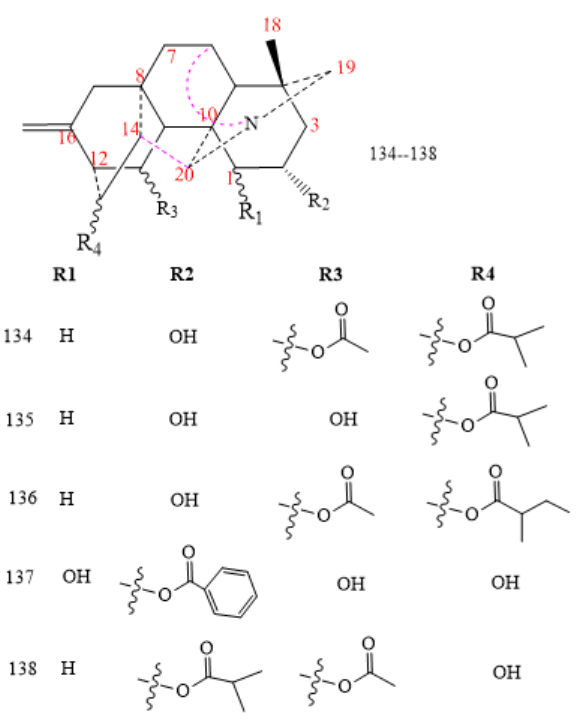




\subsection{4. $\mathrm{C}_{20}$-Hetidine Class}

The smallest group in the hetidine classification consists of three compounds (139-141 in Figure 16) $[99,101,102]$. It is distinguished by the presence of the $\mathrm{N}=\mathrm{CH}$ group, an endocyclic double bond, and a hydroxyl at C5 in all hetidine-DAs [97-99,101]. Rotundifosine F (structure 139 in Figure 16) exhibits a cardicine chloride in C17, whereas the DA 140 shows the hordenine group in the same position, and DA 141 brings a (2-methoxyethyl)-benzene ethanol moiety [99].

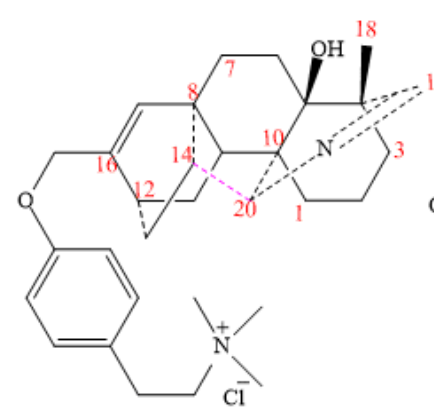

139

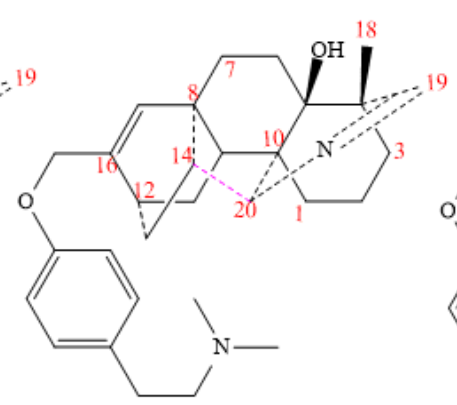

140

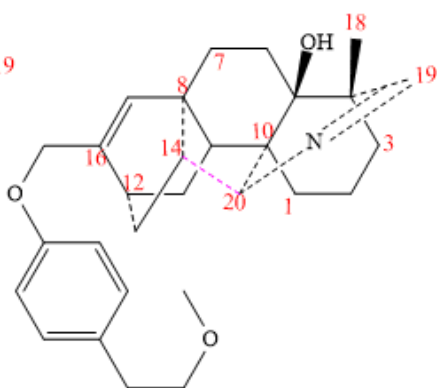

141

Figure 16. $C_{20}$-hetidine DAs.

\subsection{5. $\mathrm{C}_{20}$-Vakognavine Class}

Most vakognavine DAs (142-147 in Figure 17) come from Aconitum and Delphinium. Structurally, they have a rare double bond between $\mathrm{C} 16$ and C17, an aldehyde group in C19, and a characteristic N-Me group [56,93,99,103-105].
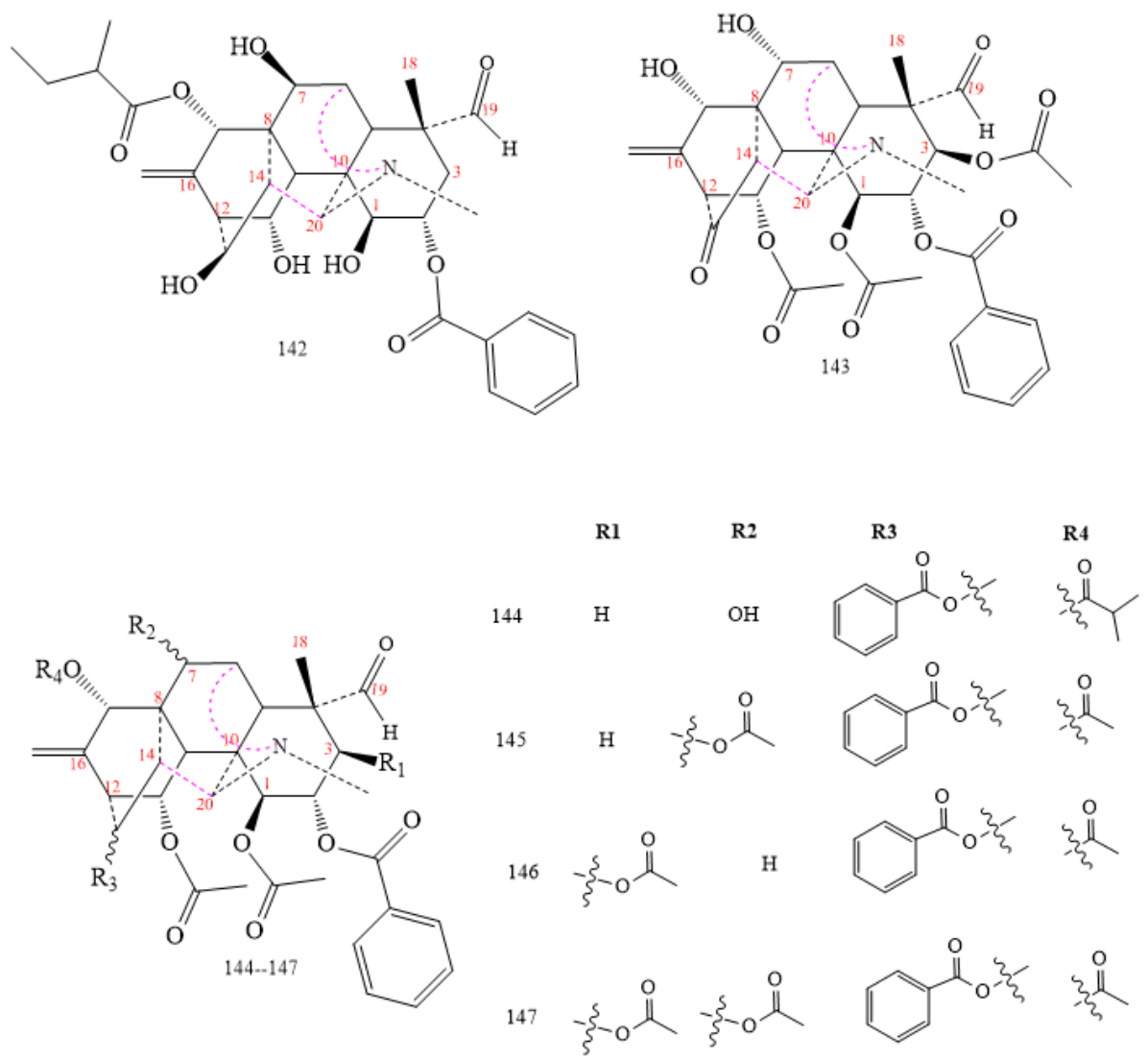

Figure 17. $C_{20}$-vakognavine Das. 


\subsection{6. $\mathrm{C}_{20}$-Napelline Class}

There are few alkaloids in this class (148-153 in Figure 18). DA 148 have an N=C19 and an endocyclic double bond; DA 149 a lactam fragment [73,106,107]. Aconicarmichinium A tri-fluoroacetate, aconicarmichinium B trifluoroacetate, and aconicarmichinium C chloride (151-153), obtained from the alcohol iminium salts of $A$. carmichaelii [107], complete the class.
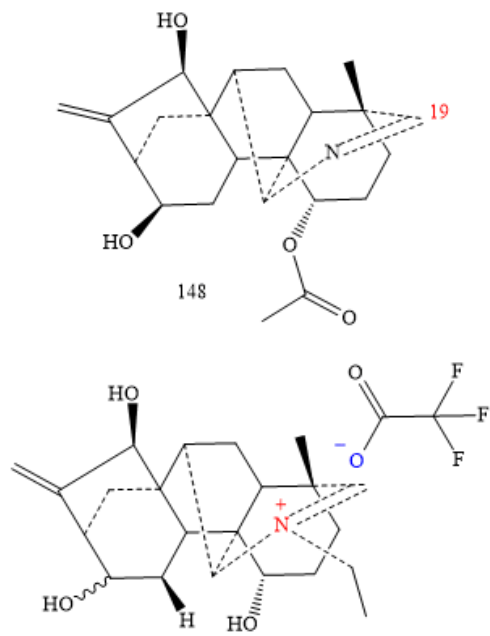

151

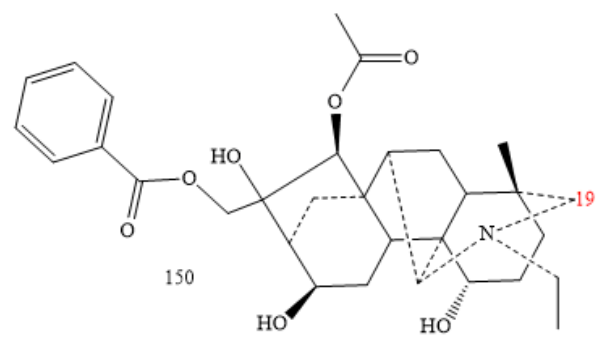

Figure 18. $\mathrm{C}_{20}$-napelline DAs.

\subsection{7. $C_{20}$-Anopterine Class}

DAs in this classification come from Anopterus/Anopterus macleayanus species (154-156 in Figure 19). All anopterine DAs are similar; they have two hydroxyl groups, an N-Me and an endocyclic double bond [108]. They differ only the substituent in C11; compounds 154 and 155 show a hydroxymethyl butenoate, whereas the DA-156 exhibits an O-benzoyl group [108].
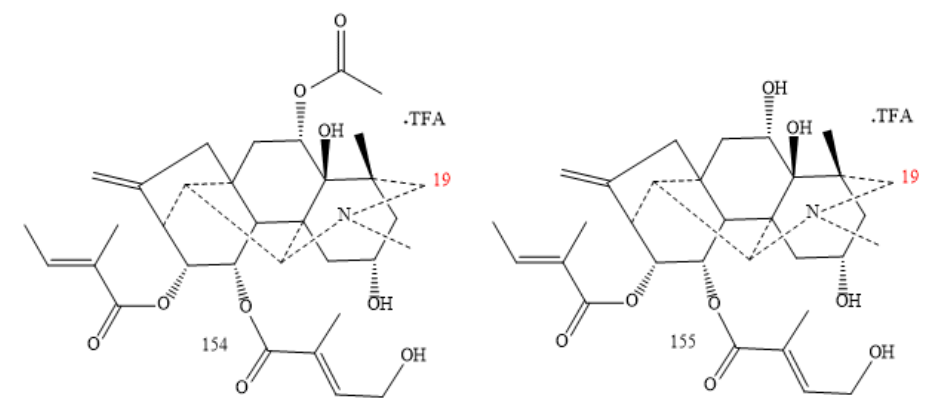
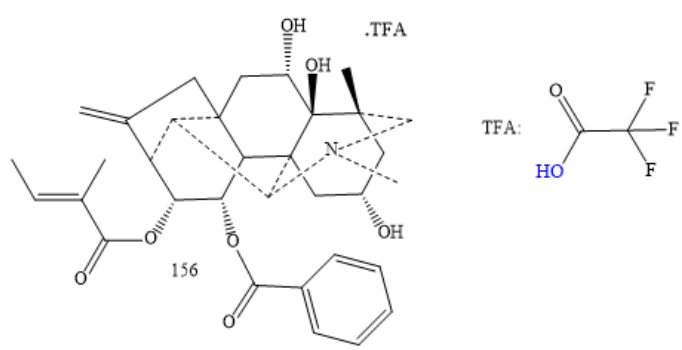

Figure 19. $\mathrm{C}_{20}$-anopterine DAs. 


\subsection{8. $\mathrm{C}_{20}$-Rearranged Classes}

They are new $\mathrm{C}_{20}$-DAs (157-160 in Figure 20) with rearranged carbon skeletons.

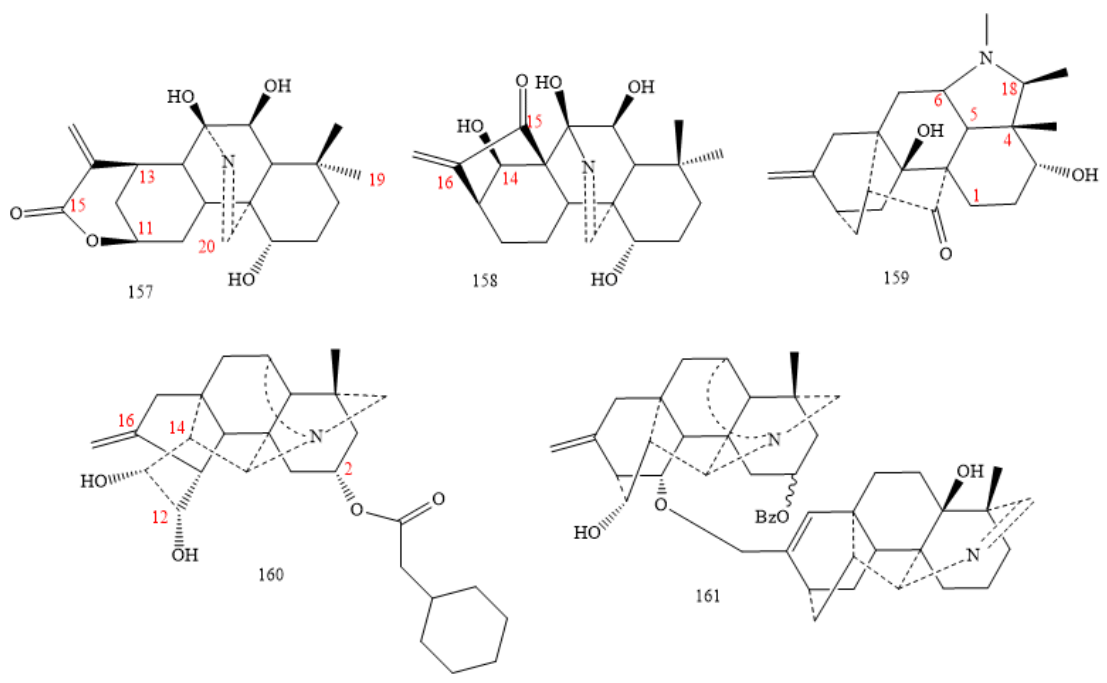

Figure 20. $C_{20}$-rearranged DAs.

Kaurine A and B (157, 158 in Figure 20) come from Isodon rubescens. These two compounds show a 7,20-aza-ent-kaurane skeleton instead of a 19,20. Moreover, the DA-157 exhibit a lactone between C11 and C16 [74,88,109,110].

Compound 159 is isolated from D. grandiflorum. Compared to the hetisine class skeleton, the bond between the $\mathrm{N}$ atom and $\mathrm{C} 17$ was open due to forming a five-member ring, including C4, C5, C6, C18, and the $\mathrm{N}$ atom [109].

DA 160 is obtained from the roots of Delphinium trichophorum. Its skeleton contains a rearranged C-ring, a pentacyclic structure, and is not hexacyclic, as in a hetisane class [111,112].

Almost all of the $\mathrm{C}_{20}$-diterpenoid alkaloids contain oxygenated groups. However, in contrast to the $\mathrm{C}_{19}$-diterpenoid alkaloids, $\mathrm{C}_{20}$-DAs possess the following distinctive features [113-157]:

(i) Most of them do not contain a methoxy group in their structures as $\mathrm{C}_{19}$-DAs [108];

(ii) Some alkaloids contain an acetoxy group or benzoyloxy ester group, or both, and do not include other ester groups [56,93];

(iii) Most $\mathrm{C}_{20}$-DAs possess exocyclic methylene, and many of them have a secondary hydroxyl function in the allylic position $[109,157]$;

(iv) Few atisine and hetidine-type alkaloids contain N,O- mixed acetal/ketal units [77,78, 99,101]

\subsection{Bis-Diterpenoid Alkaloids}

Structurally, Bis-DAs (162-169 in Figure 21) are classified into three classes, atisinedenudatine (162 in Figure 21), hetidine-hetisine (163 in Figure 21), and heteratisinehetidine (164 in Figure 21). The atisine-denudatine consists of an atisine-type and a denudatine-type $\mathrm{C}_{20}$-DA, characterised by an O-ether linkage between atisine and denudatine. Hetidine-hetisine comprises a hetidine-type and a hetisine-type $\mathrm{C}_{20}$-DA with an oxygen atom linking hetidine and hetisine in the compound. Heteratisine-hetidine links a lactone-type $\mathrm{C}_{19}$-DA and a hetidine-type $\mathrm{C}_{20}$-DA [154-158]. 

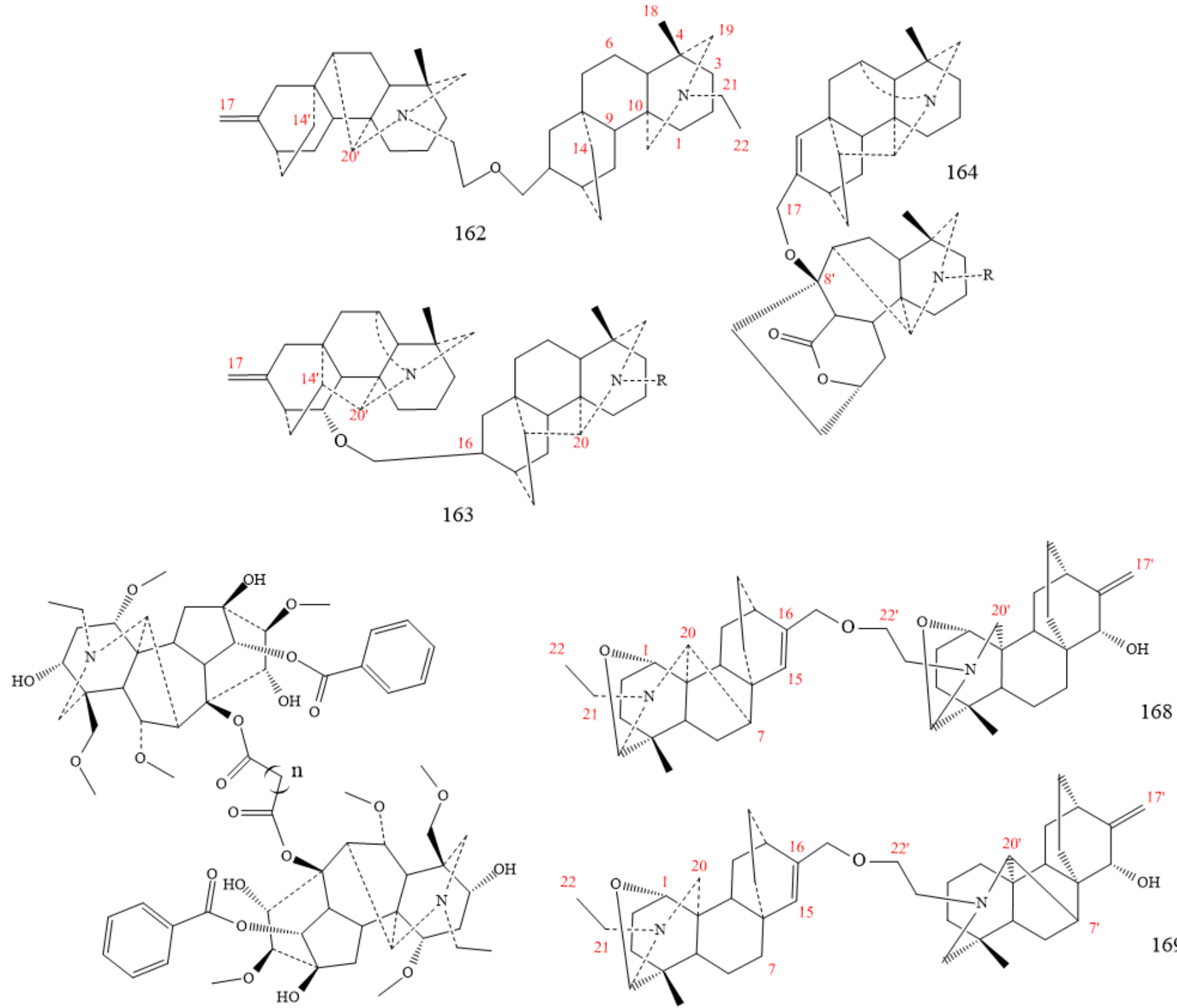

$165: \mathrm{n}=5$

$166: \mathrm{n}=6$

167: $\mathrm{n}=7$

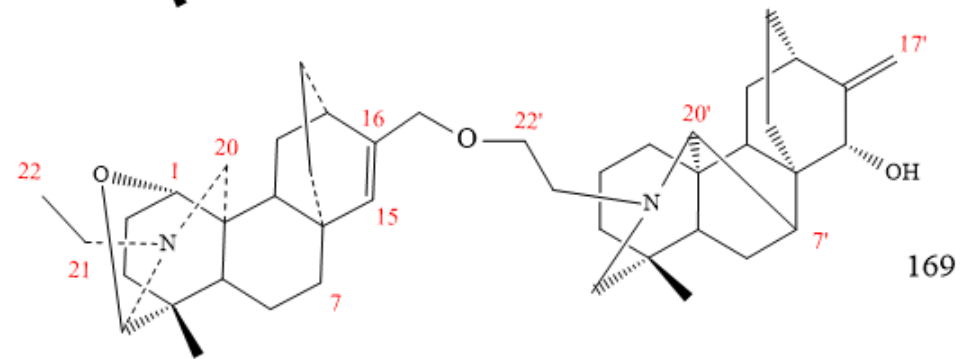

Figure 21. Bis-diterpenoid alkaloids.

\section{Marine Diterpenoid}

Natural products of marine origin have become progressively substantial lead structures for drug discovery [159-166]. However, their structural variety often distinguishes them from products obtained from plants [159]. In this context, the scant availability of material from natural sources often poses a significant limitation to their utilisation.

Diterpenoids obtained from soft corals of the genus Xenia show a vast range of biological activities such as antiproliferative [160], antiangiogenic [161], or bactericidal [162] effects.

The dichloromethane extract from the Formosan soft coral Xenia blumi showed significant cytotoxicity to A549 (human lung adenocarcinoma), HT-29 (human colon adenocarcinoma), and P-388 (mouse lymphocytic leukaemia) cell cultures [163-165]. Bioassay-guided fractionations of this extract resulted in the isolation of eight new Xenia-diterpenoids, blumiolide-A (170 in Figure 22), blumiolide-B (171 in Figure 22), 9-deoxy-isoxeniolide-A (172 in Figure 22), 9-deoxy-7,8-epoxy-isoxeniolide-A (173 in Figure 22), 9-deacetoxy-7,8- 
epoxy-13-epi-xenicin (174 in Figure 22), 9-deoxy-7,8-epoxy-xeniolide-A (175 in Figure 22), blumiolide-C (176 in Figure 22), and blumicin-A (177 in Figure 22) [167-169].
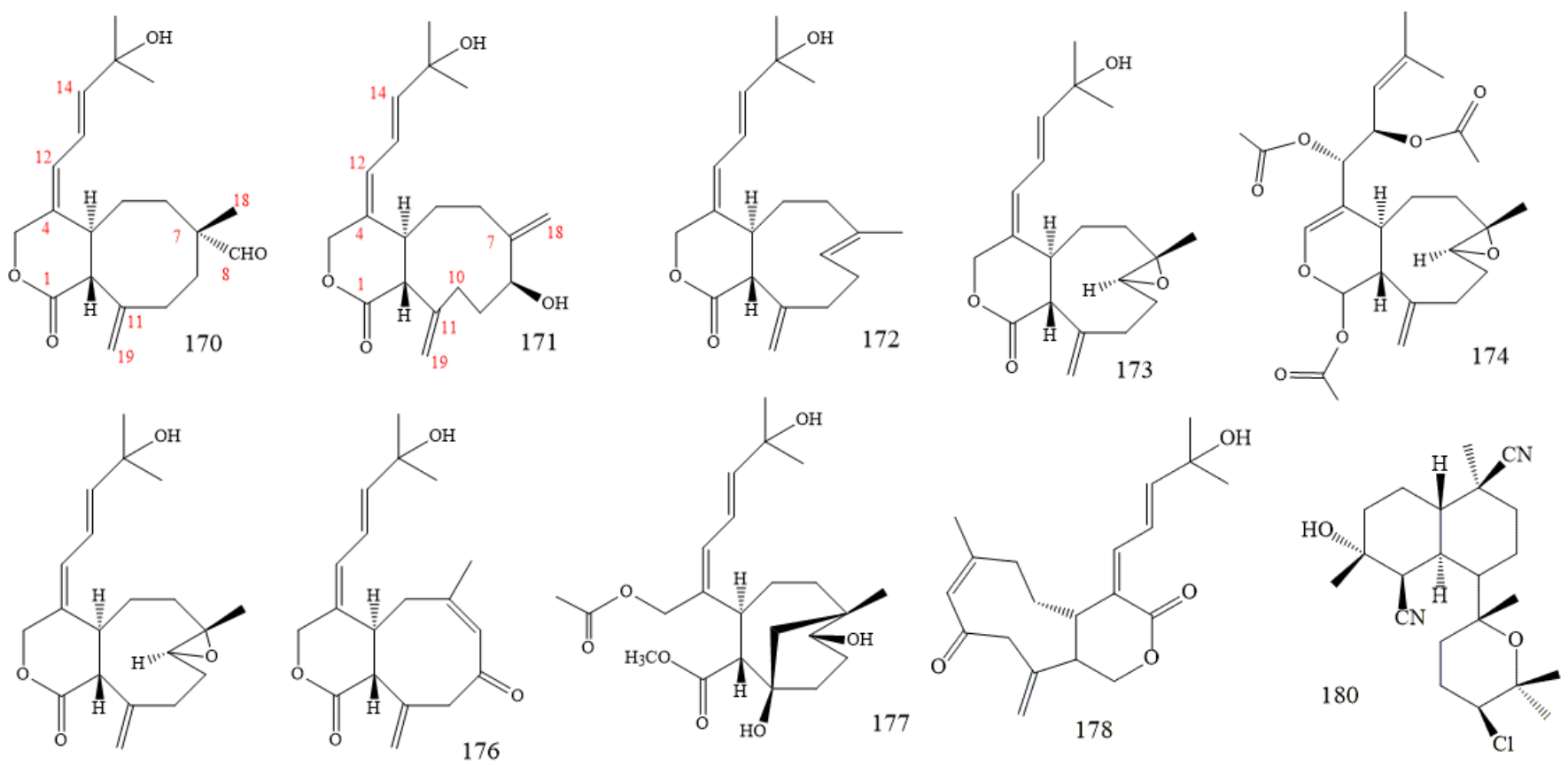

175

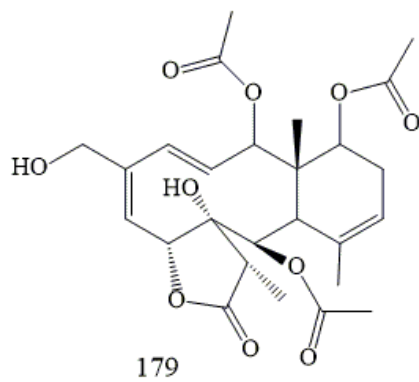

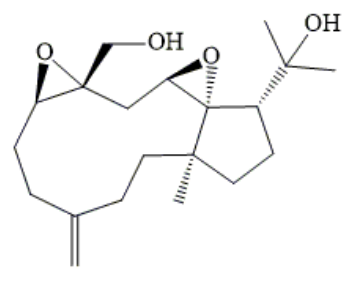

181

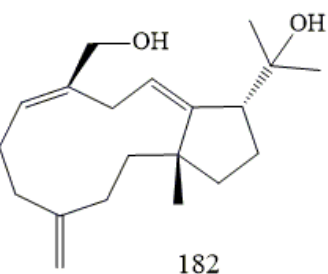

182

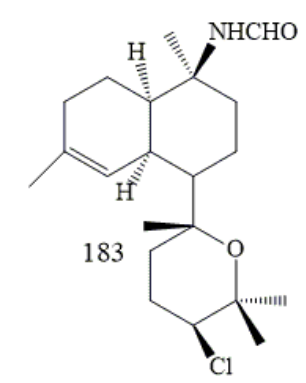

Figure 22. Marine diterpenoids.

Xenia-diterpenoid blumiolide C (178 in Figure 22), isolated from X. blumi, exhibits a potent in vitro antiproliferative activity (ED50 values of $1.5 \mu \mathrm{m}$ and $0.6 \mu \mathrm{m}$ against the human colon cancer cell line HT-29 and the mouse P-388 leukaemia line, respectively). Structurally, blumiolide $C$ is distinct from most Xenia-diterpenoids because of the presence of a $Z$, rather than the commonly found $E$, double bond as part of the nine-membered ring $[160,162]$.

Pachyclavulide B (179 in Figure 22), isolated from the Okinawan soft coral, Pachyclavularia violacea, is a briarane-type diterpenoid containing eight chiral centres and a highly oxygenated tricyclic system [168]. It exhibits moderate growth-inhibitory activity against cancer cells (SNB-75) of the central nervous system [169].

Kalihinol A (180 in Figure 22), isolated from the Guamanian marine sponge, Acanthella $\mathrm{sp}$., is a richly functionalised tricyclic diterpenoid with isocyano and hydroxyl tetrahydropyranyl and chlorine functions [170]. Biological activity, including antimicrobial [170-172], antifungal [170-176], cytotoxic [174], anthelmintic [173-177], and antifouling [178-182], have been reported. Kalihinol A, obtained from the Okinawan sponge, Acanthella sp., strongly inhibits proliferation of the malaria parasite, Plasmodium falciparum (EC50 $\left.1.2 \times 10^{-9} \mathrm{M}\right)$, and express a remarkable selective index (SI 317), defined as the ratio of FM3A cell cytotoxicity to P. falciparum $[183,184]$. 
Stolonidiol (181 in Figure 22) and stolonitriene (182 in Figure 22) are dolabellane-type diterpenoids isolated from the Okinawan marine soft coral, Clavularia sp. [185,186]. Most dolabellane-type diterpenoids possess trans-bicyclo tetradecane and exhibit antimicrobial, antitumor, and antiviral activity $[187,188]$. Stolonidiol is unique for multiple biological activities and expresses potent cytotoxic activity toward P388 leukaemia cells (IC50 $0.015 \mu \mathrm{g} \mathrm{mL}^{-1}$ ) and ichthyologic activity toward killifish, Oryzias latipes (minimum lethal concentration: $10 \mu \mathrm{g} \mathrm{mL}^{-1}$ ) [185].

Kalihinane-type diterpenoid possessing cis or trans-decalin and tetrahydropyran or tetrahydrofuran as its fundamental skeleton is a highly functionalised marine diterpenoid bearing isocyano, isothiocyanate, formamide, hydroxy, and (or) chlorine groups [189-192]. Most kalihinane-type diterpenoids exhibit antimicrobial [171,172,189], antifungal [172,175,189], cytotoxic [174], anthelmintic [175,189], antifouling [190], and antimalarial [191] activities.

Kalihinene X (183 in Figure 22), isolated from the Japanese marine sponge, Acanthella cavernosa, is a formamide kalihinane-type diterpene with cis-decalin chlorinated tetrahydropyran moieties [190]. Kalihinene $X$ inhibits the attachment and metamorphosis of cyprid larvae of the barnacle, Balanus amphitrite, with EC50 of $0.49 \mu \mathrm{g} \mathrm{mL}^{-1}$, which does not show toxicity at this concentration [192].

\section{Toxicity}

Regardless of the broad domain of 'DAs' biological activities obtained from Aconitum and Delphinium plants, DA plants and their compounds are cardiotoxins and potent neurotoxins, despite being evaluated as decorative plants [113-119].

Toxic DAs mainly affect the central nervous system and the heart, with gastrointestinal side effects. Overdose can lead to death due to the development of ventricular arrhythmias and cardiac arrest $[114,119,120]$. With the ubiquitous tradition of using DAs as herbal medicines, often disguised as ornamental plants, poisoning cases are notoriously widespread [119,121].

'DAs' toxicity is mainly due to the diester diterpene alkaloids ( $\mathrm{C}_{19}$-Aconitine class), which exhibit two ester groups, an acetyl moiety on $\mathrm{C} 8$ and a benzoyl $\backslash$ anisoyl moiety on $\mathrm{C} 14$ [114,122]. Therefore, the de-esterification of $\mathrm{C}_{19}$-Aconitine DAs reduces their toxicity. For example, the mono-ester diterpene alkaloid benzoylaconine is 200-fold less toxic than aconitine [114]. Furthermore, alkaline hydrolysis of acetyl and benzoyl in aconitine produces aconine (alcohol amine diterpenoid alkaloid), which is less than 1000-fold as toxic as aconitine [122].

In general, the Aconitum roots used in traditional medicines follows specialised processing methods, such as soaking, boiling, or hydrolysing; this causes a decrease in aconitine derivatives toxicity (benzylaconine or aconine) $[147,150]$. When comparing the proportion of aconitine in raw chuanwu to processed chuanwu (soaked or boiled), the balance of aconitine in the raw material is more remarkable. For this reason, the exposure to poisoning is higher when using raw chuanwu [119].

The cardiotoxicity and neurotoxicity of aconitines are in virtue of their actions on the voltage-sensitive sodium channels of the cell membranes of excitable tissues, including the myocardium, nerves, and muscles. Aconitine binds to open sensitive, high-voltage sodium channels, causing continuous sodium channel activation, becoming resistant to excitation. The electrophysiological mechanism of induction of arrhythmias due to delayed post-depolarisation and early post-depolarisation is triggered [114,119,121-123].

Aconitine 'DAs' arrhythmic properties are part of its cholinergic (anticholinergic) effects mediated by the vagus nerve. Aconitine has a positive inotropic effect by prolonging sodium's influx during the action potential [114,122].

It has antihypertensive and bradycardia actions by virtue of the activation of the ventral nucleus in the hypothalamus. By acting on voltage-sensitive sodium channels in axons, aconitine inhibits neuromuscular transmission by reducing acetylcholine's induced quantitative release. On the other hand, aconitine DAs can cause severe contractions of the ileum by releasing acetylcholine from the posterior node cholinergic nerves [114,122]. 
Studies conducted on the effect of aconitine in mice concluded that it induces cell death by promoting excess $\mathrm{Ca}^{2+}$ in the ventricular muscle cells, causing disruption of the $\mathrm{Na}^{+} / \mathrm{Ca}^{2+}$ exchange system and reducing the regulation of the sarco-endoplasmic network of $\mathrm{Ca}^{2+}$-ATPase $[124,125]$.

Three diterpene mono-ester alkaloids (MEA) and three diterpene di-ester alkaloids (DEA), tested on fish for cardiac toxicity, revealed how acetate in the C8 position of DEA contributes most to cardiac toxicity [126-128].

Unfortunately, there is no specific treatment for Aconitum poisoning. In contrast, supportive cardiovascular therapy is usual in poisoning cases [114,122].

\section{Bio-Activities of DAs}

\subsection{Analgesic Activities}

Opioids, salicylates, propionic acid derivatives, oxicam, and other non-steroidal anti-inflammatory drugs, usually used to control pain, have harmful side effects in gastrointestinal damage by inhibiting prostaglandin production in addition to the potential for addiction and adverse effects on the nervous system to opioid users [129].

Over the past ten years, studies have examined the effect of plant parts and alkaloids derived from them, such as A. carmichaelii [130], Aconitum weixiense [30], Aconitum bulleyanum [131], Aconitum baikalensis [132], and Aconitum brachypoumi [133], which has seen them used as analgesics [20,21,30,72,130-132,134-137].

Investigations on the effectiveness of analgesics obtained from $\mathrm{C}_{18}$ - and $\mathrm{C}_{19}$-DAs showed that aconitine and lappaconitine affect sodium channels. Aconitine inhibits nerve conduction by continuous depolarisation, while lappaconitine may block $\mathrm{Na}+$ channels and act as a local anaesthetic $[129,138]$.

Lappaconitine (C18-DAs) shows pain-relief properties. However, lappaconitine sulfate, obtained by the modification of lappaconitine, exerts a more noticeable analgesic action than lappaconitine, which is poorly soluble in water $[139,140]$.

Studies on the analgesic activity of $\mathrm{C}_{19}$-DAs demonstrated that compound 60 in Figure $5 b$, extracted from $A$. carmichaelii, exerts an analgesic effect on mice when used in acetic acid with a non-toxic dose of $0.5 \mathrm{mg} / \mathrm{kg}$ of body weight [141].

Compounds 100 in Figure 10 and 101 in Figure 11, administered in acetic acid using doses of $1.0,0.3$, and $0.1 \mathrm{mg} / \mathrm{kg}$, showed a weak analgesic effect on mice using the higher amount of $1 \mathrm{mg} / \mathrm{kg}$, with a pain suppression rate of $78.34 \%$, whereas the rate was less than 20\% for compounds 98 and 99 in Figure 10 [21]. The lack of the methoxy group in C6, as for compounds 94 and 95, seems to exert a fairly noticeable effect on the analgesic activity, whereas the presence of a methoxyl group in C1, as for the compounds 98 and 99 , significantly decreases the activity [21].

Other C19-DAs exhibit analgesic effects with low toxicity as guiwuline (compound 90 in Figure 9) [72], bulleyaconitines A, foresaconitines, and yunaconitines [131].

The structure-activity relationship (SAR) analysis revealed the fundamental structures necessary for observing the analgesic activity of the $\mathrm{C}_{19}$-DAs. For example, substituents in C8 should be either the acetoxyl or ethoxyl group, a tertiary amine is essential in the cyclohexane ring, and substituents in C14 different from an aromatic ester would reduce the effectiveness. Furthermore, the hydroxylation at C15 is requisite to undergo bioactivation $[5,135]$.

The characteristic skeletons, showing low toxicity in $\mathrm{C}_{20}$-DAs, encouraged researchers to conduct studies on their analgesic effects. In contrast to the substantial toxicity of $\mathrm{C}_{18^{-}}$ DAs and $\mathrm{C}_{19}$-DAs, $\mathrm{C}_{20}$-DAs may be effective candidate drugs for the management of pain treatments. In addition, the sulfonated compound (157 in Figure 20), extracted from the lateral roots of $A$. carmichaelii, also showed a significant analgesic activity [142].

\subsection{Anti-Inflammatory Activities}

NSAIDs (salicylates, acetic acid derivatives, profenes, oxycamates, pyrazolidine derivatives, selective cyclooxygenase-2 inhibitors, and phenamic acids) are the most com- 
monly used analgesics and anti-inflammatory drugs. They have many side effects on the digestive and nervous systems [115]. Based on studies conducted on $\mathrm{C}_{19}$-DAs extracted from Aconitum and Delphinium, diterpenoid alkaloids can interact with neurotransmitters, making them good candidates as anti-inflammatory drugs [30,37,55,70,105,129,130,143-146].

Compound 144 in Figure 17 inhibits the activity of cyclooxygenase-2 (COX-2) with inhibitory concentration $\left(\mathrm{IC}_{50}\right)$ nearly equal to that of acetylsalicylic acid $(29.75 \mu \mathrm{M}$ and $29.30 \mu \mathrm{M}$, respectively); this is what makes it a possible alternative to aspirin [105].

The activity of compound 55 in Figure 5b and compound 87 in Figure 8 on inhibiting NO production in lipopolysaccharide cells (LPS) stimulated the macrophage cell line RAW 264.7, with a behaviour similar to dexamethasone. $\mathrm{IC}_{50}$ values were $7.46 \pm 0.89 \mu \mathrm{M}$ and $8.09 \pm 1.31 \mu \mathrm{M}$ for compounds 87 and 55, respectively, and $8.32 \pm 1.45 \mu \mathrm{M}$ for dexamethasone $[68,70]$. Swatinine (compound 64 in Figure 6, obtained from Aconitum baikalense has an anti-inflammatory activity similar to indomethacin, with an inhibition rate of $38.71 \%$ and $42.02 \%$, respectively [55]. Therefore, given their particular activity, various DAs can provide good resources for exploring promising anti-inflammatory drugs.

Bulleyanines A and B (168 and 169 in Figure 21, respectively), two novel compounds, were isolated from Aconitum bulleyanum. Compound A showed a marked effect on antiinflammatory activity with an inhibition rate of $74.60 \%\left(40 \mu \mathrm{mol} \mathrm{L}^{-1}\right)$, compound B showed as inactive, as compared to positive control dexamethasone (78.70\%) at $100 \mu \mathrm{g} \mathrm{mL}^{-1}$ [158].

\subsection{Antimicrobial Activities}

Several researchers demonstrate the antimicrobial activity of some DAs. For example, sinchiangensine (compound 59 in Figure $5 b$ ) has potent antibacterial activity against Staphylococcus aureus with minimum inhibitory concentration (MIC) value $0.147 \mathrm{mmol} \mathrm{mL}^{-1}$; furthermore, lipodeoxyaconitine (analogue of sinchiangensine) is active against the same bacterium with MIC value $0.144 \mathrm{mmol} \mathrm{mL}^{-1}$ [144].

Some $\mathrm{C}_{20}$-vakognavine compounds, e.g., carmichaedine (compound 144 in Figure 17), show activity against Bacillus subtilis with MIC of $8 \mathrm{mmol} \mathrm{mL}^{-1}$ [104]. Besides, some aconitine-type DAs such as vilmorine $\mathrm{D}$, vilmorrianine $\mathrm{A}$, and yunaconitine exhibit antibacterial activity against $S$. aureus and B. subtilis [145].

Compound 50A in Figure 5b, obtained from the roots of Aconitum duclouxi, also show antibacterial activity against $B$. subtilis with an MIC of $147.73 \mathrm{mmol} \mathrm{L}^{-1}$; moreover, compounds 50A and 50B show antifungal activity against Candida albicans with MIC of 51.84 and $128 \mathrm{mg} \mathrm{mL}^{-1}$, respectively $[146,147]$.

Additionally, aconicaramide, extracted from the lateral roots of $A$. carmichaelii, displays equinoctial antibacterial activity against Macrococcus caseolyticus, Staphylococcus epidermidis, and S. aureus (MIC 200, 400, and $800 \mathrm{mg} \mathrm{mL}^{-1}$, respectively) [84].

Oleracein E demonstrated antibacterial activity against S. aureus, M. caseolyticus, Klebsiella pneumonia, and Streptococcus pneumoniae (MIC: 50, 200, 200, and $200 \mathrm{mg} \mathrm{mL}^{-1}$, respectively) [84].

Extensive laboratory experiments are helpful promoters for the preparation of new antimicrobial formulations.

\subsection{Antioxidant Activities}

Diterpenoid alkaloids showed auspicious 1,1-diphenyl-2-picrylhydrazyl (DPPH)-like scavenging activity. Aconitine-type $\mathrm{C}_{19}$-DAs could be suitable antioxidants because of their ability for binding to metal ions [105]. Swatinine compounds (64 and 73 in Figure 6) offered an effective DPPH radical scavenging ratio of $65.3 \%$ and $63.4 \%$, respectively, at $1 \mu \mathrm{M}$, whereas butylated hydroxytoluene (standard antioxidant) inhibited to $92.1 \%$ at the same concentration [55]. These results indicate that $\mathrm{C}_{19}$-DAs could also offer new antioxidant agents, selecting substances with lower toxicity in this group. 


\subsection{Cytotoxic Activity}

Various 'DAs' anticancer activities have been widely studied from different parts of Aconitum, Consolida, and Delphinium in the last decade [148]. The most effective natural DAs with anticancer properties in Aconitum were $\mathrm{C}_{19}$-DAs and some derivatives of $\mathrm{C}_{20}$-DAs. SAR analysis showed that DA activity increased in correspondence with simple structural modification of these compounds, but their anticancer mechanisms need further studies.

Researchers examined many newly obtained DAs against the lung cancer cell lines, A549. Compounds 59 in Figure 5b [144], 135 [96,97] and 137 [96] in Figure 15, and 160 [96] and 161 [101] in Figure 20 showed appreciable cytotoxicity toward the A549 with $\mathrm{IC}_{50}<20 \mu \mathrm{M}$.

Other compounds $(\mathbf{1}, \mathbf{3}, \mathbf{4}$, and $\mathbf{6}$ in Figure 1; 22 in Figure 5) were active against liver cancer cell line HepG2 [105], and compound $\mathbf{1 4 4}$ in Figure 17 showed perfect activity against HepG2 with $\mathrm{IC}_{50}$ of $3.65 \mu \mathrm{M}$ [105]. In contrast, DA-59 (Figure 5b) [144] and compound 161 (Figure 20) showed $\mathrm{IC}_{50}$ of $9.18 \mu \mathrm{M}$ and $18.52 \mu \mathrm{M}$ against liver cancer cell line SMCC-7721 [101].

DA-153 (Figure 18) has a strong effect against human prostate carcinoma with $\mathrm{IC}_{50}$ of $3.1 \mu \mathrm{M}$ [108,149]; furthermore, DA-112 (Figure 13) shows a significant action against human breast adenocarcinoma MCF-7 cell line with $\mathrm{IC}_{50} 3.16 \mu \mathrm{M}$ [79].

Compounds 51 [150] and 59 [144] (Figure 5b), and 161 (Figure 20) [101,151], characterize an anticancer activity vs. leukaemia cell lines HL-60, and DAs 51-55 (Figure 5b) exerted potent action against line K562 [150].

SAR of antitumor DAs indicates that the number and position of the hydroxyl and ester groups in $\mathrm{C}_{19}$-DAs may play an essential role in cytotoxicity, especially substitutions in C1, C3, C6, and C8 [50,53,92,105,144,148,152,153].

Three new bis-DAs derived from genus Aconitum (165-167 in Figure 21) present remarkable cytotoxic activity in vitro against lung cancer A-549, colon cancer HCT-15, and breast cancer MCF-7 cells; their IC50s were $<28 \mu \mathrm{M}$ [154].

\section{Conclusions}

Over the past decade, more than 300 DAs were discovered and extracted from plants, particularly Aconitum, Delphinium, and Consolida genera.

Structurally, DAs derived from four isoprenyl 'units' condensation subdivide into more than 45 classes based on their central structure arrangement and different substituent. These compounds display a broad area of pleasant chemical properties and biological activity, such as analgesic, anti-inflammatory, antimicrobial, cytotoxic activity, and toxic effects. Their toxic effect is manifested in the nervous and cardiovascular systems, acting as potent neurotoxins and cardiotoxins. The toxicity of $\mathrm{C}_{18}$-DAs and $\mathrm{C}_{19}$-DAs groups has justified their development into new therapeutic drugs, except glycosidic DAs, which have additional sugar moieties in their structures that facilitate their water solubility unlike the other DA groups. This observation gives future hope to discovering new chemical compounds with low toxicity and useful bio-activity in the aqueous extracts of alkaloids with SAR similar to $\mathrm{C}_{19}$-DAs. The complex nature of the diterpenoid-alkaloids SAR suggests the need for an accurate knowledge of individual compound properties to discover further safe and valuable applications of novel bioactive compounds.

The 'researchers' competition, turned to deeper study of $\mathrm{C}_{20}$-DAs after a SAR analysis, displayed their chemical structure diversity and their little toxicity compared to $\mathrm{C}_{19}$-DAs. In addition, their classification into seven groups with different SARs facilitates the search for biologically active molecules and potential new drugs.

Many research efforts, oriented to studying the anti-inflammatory, analgesic, and anticancer activity of DAs, highlighted that numerous $\mathrm{C}_{19}$-DAs and $\mathrm{C}_{20}$-DAs have noticeable effectiveness. The $\mathrm{C}_{20}$-hetisine class showed the highest possibilities with the lowest toxicity among the other DAs. For this reason, the hetisine compounds may be good starters for developing novel anticancer drugs using alkaloids. 
Author Contributions: Conceptualisation, S.A.B. and A.M.T.; resources, S.A.B.; data curation, S.A.B., A.M.T., A.T., F.L. and L.S.; writing-original draft preparation, A.M.T. and A.T.; writing-review and editing, S.A.B., F.L. and L.S.; supervision, S.A.B. All authors have read and agreed to the published version of the manuscript.

Funding: This research received no external funding.

Institutional Review Board Statement: Ethical review and approval were waived for this review, which does not report new experimental results obtained by authors but contains a summary of already published data.

Informed Consent Statement: Not applicable.

Data Availability Statement: Not applicable.

Conflicts of Interest: The authors declare no conflict of interest.

Sample Availability: Not applicable.

\section{References}

1. Xiao, P.-G. A pharmacophylogenetic study of Aconitum L. (Ranunculaceae) from China. Acta Phytotaxon Sin. 2006, 44, 3-48. [CrossRef]

2. Yin, T.; Zhou, H.; Cai, L.; Ding, Z. Non-alkaloidal constituents from the genus Aconitum: A review. RSC Adv. 2019, 9, 10184-10194. [CrossRef]

3. Shen, Y.; Zuo, A.X.X.; Jiang, Z.Y.; Zhang, X.M.; Wang, H.L.; Chen, J.J. Five New $\mathrm{C}_{19}$-Diterpenoid Alkaloids from Aconitum hemsleyanum. Helv. Chim. Acta 2010, 93, 482-489. [CrossRef]

4. Kiss, T.; Cank, K.; Orbán-Gyapai, O.; Liktor-Busa, E.; Rutkovska, S.; Pučka, I.; Hohmann, J.; Csupor, D. Screening for diterpene alkaloids in the Spiraea genus. Planta Med. 2015, 81, PM_19. [CrossRef]

5. Wang, F.P.; Chen, Q.H.; Liang, X.T. Alkaloids toxic to livestock. In The Alkaloids: Chemistry and Biology; Cordell, G.A., Ed.; Elsevier Science: New York, NY, USA, 2009; Volume 67, pp. 1-282.

6. Wang, F.P.; Chen, Q.H. The $\mathrm{C}_{19}$-Diterpenoid alkaloids. In The Alkaloids: Chemistry and Biology; Cordell, G.A., Ed.; Elsevier Science: New York, NY, USA, 2010; Volume 69, pp. 1-609.

7. Wang, F.P.; Liang, X.T. $C_{20}$-Diterpenoid alkaloids. In The Alkaloids: Chemistry and Biology; Cordell, G.A., Ed.; Elsevier Science: New York, NY, USA, 2002; Volume 59, pp. 1-280.

8. Wang, F.-P.; Chen, Q.-H.; Liu, X.-Y. Diterpenoid alkaloids. Nat. Prod. Rep. 2010, 27, 529-570. [CrossRef] [PubMed]

9. Hao, D.C.; Gu, X.J.; Xiao, P.G. Medicinal Plants: Chemistry, Biology and Omics, 1st ed.; Woodhead Publishing: Sawston, Cam-bridge, MA, USA, 2015; pp. 253-292.

10. Ameri, A. The effects of Aconitum-alkaloids on the central nervous system. Prog. Neurobiol. 1998, 56, 211-235. [CrossRef]

11. Bessonova, I.A.; Saidkhodzhaeva, S.A. Hetisane-Type Diterpenoid Alkaloids. Chem. Nat. Compd. 2000, 36, 419-477. [CrossRef]

12. Pelletier, S.W.; Joshi, B.S. Carbon-13 and Proton NMR Shift Assignments and Physical Constants of Norditerpenoid Alkaloids. In Alkaloids: Chemical and Biological Perspectives, 1st ed.; Pergamon: New York, NY, USA, 2001; pp. 297-564.

13. Joshi, B.S.; Pelletier, S.W.; Srivastava, S.K. Carbon-13 and proton NMR shift assignments and physical constants of diterpenoid alkaloids. In Alkaloids: Chemical and Biological Perspectives, 1st ed.; Pergamon: New York, NY, USA, 1999; p. 289.

14. Hale, K.J.; Manaviazar, S. Second Supplements to the 2nd Edition of ' 'Rodd's Chemistry of Carbon Compounds; Sainsbury, M., Ed.; Elsevier: Amsterdam, The Netherlands, 1991; p. 1.

15. Rahman, A.-U.; Choudhary, M.I. Diterpenoid and steroidal alkaloids. Nat. Prod. Rep. 1999, 16, 619-635. [CrossRef]

16. Ping, A.; Chen, Q.H.; Chen, D.L.; Jian, X.X.; Wang, F.P. Note: Two new $\mathrm{C}_{19}$-diterpenoid alkaloids from Aconitum kongboense. J. Asian Nat. Prod. Res. 2004, 6, 151-154. [CrossRef]

17. Peng, C.S.; Wang, F.P.; Wang, J.Z.; Jian, X.X. Two new bisnorditerpenoid alkaloids sinomontanines D and E from Aconitum sinomontanum. Acta Pharm. Sin. B 2000, 35, 201-203.

18. Zou, C.-L.; Cai, L.; Ji, H.; Xie, G.-B.; Wang, F.-P.; Jian, X.-X.; Song, L.; Liu, X.-Y.; Chen, D.-L.; Chen, Q.-H. A novel approach to the taxane $\mathrm{ABC}$ ring system through chemical conversion from $\mathrm{C}_{19}$-diterpenoid alkaloid deltaline. Tetrahedron 2008, 64, 7594-7604. [CrossRef]

19. Lin, L.; Chen, D.L.; Liu, X.Y.; Chen, Q.H.; Wang, F.P. Trichocarpinine, a novel hetidine-hetisine type bisditerpenoid alkaloid from Aconitum tanguticum var. trichocarpum. Helv. Chim. Acta 2010, 93, 118-122. [CrossRef]

20. Meng, X.H.; Guo, Q.L.; Zhu, C.G.; Xu, C.B.; Shi, J.G. Unprecedented, $C_{19}$-diterpenoid alkaloid glycosides from an aqueous extract of "Fu Zi": Neoline 14-O-l-arabinosides with four isomeric l-anabinosyls. Chin. Chem. Lett. 2017, 28, 1705-1710. [CrossRef]

21. Guo, Q.; Xia, H.; Meng, X.; Shi, G.; Xu, C.; Zhu, C.; Zhang, T.; Shi, J. C 19 -Diterpenoid alkaloid arabinosides from an aqueous extract of the lateral root of Aconitum carmichaelii and their analgesic activities. Acta Pharm. Sin. B 2018, 8, 409-419. [CrossRef] [PubMed]

22. Song, L.; Liu, X.-Y.; Chen, Q.-H.; Wang, F.-P. New C19- and C18-Diterpenoid Alkaloids from Delphinium anthriscifolium var. savatieri. Chem. Pharm. Bull. 2009, 57, 158-161. [CrossRef] 
23. Song, Z.-J.; Chen, W.-Q.; Du, X.-Y.; Yuan, Y.-F.; Xu, H.-H. Anthriscifolcine A, a C 18 -diterpenoid alkaloid. Acta Crystallogr. Sect. E Struct. Rep. Online 2011, 67, o395. [CrossRef] [PubMed]

24. Shan, L.-H.; Zhang, J.-F.; Gao, F.; Huang, S.; Zhou, X.-L. C18-Diterpenoid alkaloids from Delphinium anthriscifolium var. majus. J. Asian Nat. Prod. Res. 2017, 20, 423-430. [CrossRef]

25. Shan, L.; Zhang, J.; Chen, L.; Wang, J.; Huang, S.; Zhou, X. Two New C18-Diterpenoid Alkaloids from Delphinium anthriscifolium. Nat. Prod. Commun. 2015, 10, 2067-2068. [CrossRef]

26. Zhang, S.-Y.; Jiang, Y.; Bi, Y.-F.; Yan, W.-J.; Zhang, Y.-B. Diterpenoid alkaloids from Aconitum kirinense. J. Asian Nat. Prod. Res. 2013, 15, 78-83. [CrossRef] [PubMed]

27. Mu, Z.-Q.; Gao, H.; Huang, Z.-Y.; Feng, X.-L.; Yao, X.-S. Puberunine and Puberudine, Two New $\mathrm{C}_{18}$-Diterpenoid Alkaloids from Aconitum barbatum var. puberulum. Org. Lett. 2012, 14, 2758-2761. [CrossRef]

28. Li, J.; Chang, H.; Zhao, W.; Pi, H.; Ruan, H.; Zhang, P. New Alkaloids from Aconitum vaginatum. Helv. Chim. Acta 2014, 97, 689-693. [CrossRef]

29. Sham'Yanov, I.D.; Tashkhodzhaev, B.; Mukhamatkhanova, R.F.; Sultankhodzhaev, M.N.; Levkovich, M.G.; Abdullaev, N.; Antipin, M.Y. Sesquiterpene lactones and new diterpenoid alkaloids from Artemisia korshinskyi. Chem. Nat. Compd. 2012, 48, 616-621. [CrossRef]

30. Zhao, D.-K.; Ai, H.-L.; Zi, S.-H.; Zhang, L.-M.; Yang, S.-C.; Guo, H.-C.; Shen, Y.; Chen, Y.-P.; Chen, J.-J. Four new C 18 -diterpenoid alkaloids with analgesic activity from Aconitum weixiense. Fitoterapia 2013, 91, 280-283. [CrossRef] [PubMed]

31. Zhang, Q.; Tan, J.J.; Chen, X.Q.; Gao, Z.B.; Jia, Q.; Chen, K.X.; Li, Y.M. Two novel C 18 -diterpenoid alkaloids, sinomon-tadine with an unprecedented seven-membered ring $\mathrm{A}$ and chloride-containing sinomontanine $\mathrm{N}$ from Aconitum sinomon-tanum. Tetrahedron Lett. 2017, 58, 1717-1720. [CrossRef]

32. Shen, Y.; Ai, H.-L.; Cao, T.-W.; Wang, J.-J.; Zi, S.-H.; Zhang, X.-M.; Chen, J.-J. Three New C 19 -Diterpenoid Alkaloids from Aconitum transsectum. Helv. Chim. Acta 2012, 95, 509-513. [CrossRef]

33. Shen, Y.; Ai, H.L.L.; Zi, S.H.H.; Wang, J.J.; Zhang, X.M.; Chen, J.J. Two new C 19 -diterpenoid alkaloids from Aconitum transsectum. J. Asian Nat. Prod. Res. 2012, 14, 244-248. [CrossRef] [PubMed]

34. Xu, J.-J.; Zhao, D.-K.; Ai, H.-L.; Zhang, L.-M.; Xie, S.-Q.; Zi, S.-H.; Yang, S.-C.; Shen, Y. Three New C19-Diterpenoid Alkaloids from Aconitum forrestii. Helv. Chim. Acta 2013, 96, 2155-2159. [CrossRef]

35. Tianxing, T.; Donglin, C.; Fengpeng, W. A New $\mathrm{C}_{19}$-Diterpenoid Alkaloid from Aconitum vilmorinianum. Chin. J. Org. Chem. 2014, 34, 909-915.

36. Yin, T.-P.; Cai, L.; Li, Y.; Fang, Y.-S.; Peng, L.; Ding, Z.-T. New Alkaloids from Aconitum stapfianum. Nat. Prod. Bioprospecting 2015, 5, 271-275. [CrossRef]

37. Guo, R.; Guo, C.; He, D.; Zhao, D.; Shen, Y. Two New C 19 -Diterpenoid Alkaloids with Anti-inflammatory Activity from Aconitum iochanicum. Chin. J. Chem. 2017, 35, 1644-1647. [CrossRef]

38. Xu, J.-B.; Huang, S.; Zhou, X.-L. C 19 -diterpenoid alkaloids from Aconitum hemsleyanum var. circinatum. Phytochem. Lett. 2018, 27, 178-182. [CrossRef]

39. He, P.; Jian, X.-X.; Chen, D.-L.; Wang, F.-P. Diterpenoid Alkaloids from Aconitum longzhoushanense. Nat. Prod. Commun. 2009, 4, 19-22. [CrossRef]

40. Chen, C.L.; Tan, W.H.; Wang, Y.; Xue, Z.G.; Wan, C.P.; Yang, Z.Y.; Zhou, Z.H.; Ma, X.X.X. New norditerpenoid alkaloids from Aconitum vilmorinianum Komarov. J. Nat. Med. 2015, 69, 601-607. [CrossRef] [PubMed]

41. Liu, W.Y.; He, D.; Zhao, D.K.; Chen, Y.P.; Shen, Y. Four new $\mathrm{C}_{19}$-diterpenoid alkaloids from the roots of Aconitum ouvrardianum. J. Asian Nat. Prod. Res. 2019, 21, 9-16. [CrossRef] [PubMed]

42. He, D.; Liu, W.-Y.; Xiong, J.; Xu, J.-J.; Shen, Y. Four new C19-diterpenoid alkaloids from Aconitum hemsleyanum var. circinatum. J. Asian Nat. Prod. Res. 2018, 21, 833-841. [CrossRef]

43. Ge, Y.H.H.; Mu, S.Z.Z.; Yang, S.Y.; Lu, Y.; Zhang, J.X.; Wang, Y.; Hao, X.J. New Diterpenoid Alkaloids from Aconitum recemulosum Franch. Helv. Chim. Acta 2009, 92, 1860-1865. [CrossRef]

44. Gao, F.; Zhu, S.-A.; Wu, W.; Wang, X.-G.; Song, L. C 19 -Diterpenoid alkaloids from the roots of Aconitum hemsleyanum var. hanyuanum and their chemotaxonomic significance. Biochem. Syst. Ecol. 2010, 38, 1052-1055. [CrossRef]

45. Gao, F.; Liu, X.Y.; Wang, F.P. Three New C19-Diterpenoid Alkaloids from Aconitum hemsleyanum var. circinatum. Helv. Chim. Acta 2010, 93, 785-790. [CrossRef]

46. Forgo, P.; Borcsa, B.; Csupor, D.; Fodor, L.; Berkecz, R.; Molnár, A.; Hohmann, J. Diterpene alkaloids from Aconitum anthora and assessment of the hERG-inhibiting ability of Aconitum alkaloids. Planta Med. 2011, 77, 368-373. [CrossRef]

47. Song, B.; Jin, B.; Li, Y.; Wang, F.; Yang, Y.; Cui, Y.; Song, X.; Yue, Z.; Liu, J. C 19 -Norditerpenoid Alkaloids from Aconitum szechenyianum. Molecules 2018, 23, 1108. [CrossRef]

48. Li, G.-Q.; Zhang, L.-M.; Zhao, D.-K.; Chen, Y.-P.; Shen, Y. Two new $\mathrm{C}_{19}$-diterpenoid alkaloids from Aconitum tsaii. J. Asian Nat. Prod. Res. 2016, 19, 457-461. [CrossRef]

49. Zhang, J.-F.; Chen, L.; Huang, S.; Shan, L.-H.; Gao, F.; Zhou, X.-L. Diterpenoid Alkaloids from Two Aconitum Species with Antifeedant Activity against Spodoptera exigua. J. Nat. Prod. 2017, 80, 3136-3142. [CrossRef]

50. Jiang, H.; Huang, S.; Gao, F.; Zhen, Y.; Li, C.; Zhou, X. Diterpenoid alkaloids from Aconitum brevicalcaratum as autophagy inducers. Nat. Prod. Res. 2019, 33, 1741-1746. [CrossRef] 
51. Zhao, D.; Shi, Y.; Zhu, X.; Liu, L.; Ji, P.; Long, C.; Shen, Y.; Kennelly, E.J. Identification of potential biomarkers from Aconitum carmichaelii, a traditional Chinese medicine, using a metabolomic approach. Planta Med. 2018, 84, 434-441. [CrossRef]

52. Zong, X.-X.; Yan, G.; Wu, J.-L.; Leung, E.L.-H.; Zhou, H.; Li, N.; Liu, L. New C 19 -diterpenoid alkaloids from the parent roots of Aconitum carmichaelii. Tetrahedron Lett. 2017, 58, 1622-1626. [CrossRef]

53. Yamashita, H.; Takeda, K.; Haraguchi, M.; Abe, Y.; Kuwahara, N.; Suzuki, S.; Terui, A.; Masaka, T.; Munakata, N.; Uchida, M.; et al. Four new diterpenoid alkaloids from Aconitum japonicum subsp. subcuneatum. J. Nat. Med. 2017, 72, 230-237. [CrossRef] [PubMed]

54. Yang, L.; Zhang, Y.-B.; Zhuang, L.; Li, T.; Chen, N.-H.; Wu, Z.-N.; Wang, G.-C. Diterpenoid Alkaloids from Delphinium ajacis and Their Anti-RSV Activities. Planta Med. 2016, 83, 111-116. [CrossRef] [PubMed]

55. Begum, S.; Mumtaz, A.; Latif, A.; Ahmad, W.; Alam, S.; Nisar, M.; Zeeshan, M.; Khan, M.T.H.; Shaheen, F.; Ahmad, M. Pharmacologically active $\mathrm{C}_{19}$-diterpenoid alkaloids from the aerial parts of Aconitum laeve Royle. Rec. Nat. Prod. 2014, 8, 83-88.

56. Chen, F.-Z.; Chen, D.-L.; Chen, Q.-H.; Wang, F.-P. Diterpenoid Alkaloids from Delphinium majus. J. Nat. Prod. 2009, 72, 18-23. [CrossRef]

57. Chen, F.-Z.; Chen, Q.-H.; Wang, F.-P. C 19 -Diterpenoid alkaloids from Delphinium umbrosum. J. Asian Nat. Prod. Res. 2010, 12, 498-504. [CrossRef] [PubMed]

58. Zhang, J.F.; Shan, L.H.; Gao, F.; Huang, S.; Zhou, X.L. Five New C 19 -Diterpenoid Alkaloids from Delphinium tianshanicum WT Wang. Chem. Biodivers. 2017, 14, e1600297. [CrossRef]

59. Zhao, B.; Usmanove, S.; Aisa, H.A.A. Three new $\mathrm{C}_{19}$-diterpenoid alkaloids from Delphinium tianshanicum WT Wang. Phytochem. Lett. 2014, 10, 189. [CrossRef]

60. Shan, L.; Chen, L.; Gao, F.; Zhou, X. Diterpenoid alkaloids from Delphinium naviculare var. lasiocarpum with their an-tifeedant activity on Spodoptera exigua. Nat. Prod. Res. 2019, 33, 3254-3259. [PubMed]

61. Wada, K.; Chiba, R.; Kanazawa, R.; Matsuoka, K.; Suzuki, M.; Ikuta, M.; Goto, M.; Yamashita, H.; Lee, K.H. Six new norditerpenoid alkaloids from Delphinium elatum. Phytochem. Lett. 2015, 12, 79-83. [CrossRef]

62. Borcsa, B.; Fodor, L.; Csupor, D.; Forgo, P.; Molnár, A.; Hohmann, J. Diterpene Alkaloids from the Roots of Aconitum moldavicum and Assessment of Nav 1.2 Sodium Channel Activity of Aconitum Alkaloids. Planta Med. 2014, 80, 231-236. [CrossRef] [PubMed]

63. Xue, W.J.; Zhao, B.; Ruzi, Z.; Zhao, J.Y.; Aisa, H.A.A. Norditerpenoid alkaloids from Delphinium pseudoaemulans C.Y. Yang et B. Wang. Phytochemistry 2018, 156, 234-240. [CrossRef] [PubMed]

64. Morita, H.; Aisa, H.A.; Li, C.; Hirasawa, Y.; Arai, H. A New Diterpenoid Alkaloid, Sharwuphinine A from Delphinium sharwurense. Heterocycles 2010, 80, 607. [CrossRef]

65. Tashkhodzhaev, B. Conformational analysis of lappaconitine and heteratisine. Chem. Nat. Compd. 2010, 46, 421-425. [CrossRef]

66. Zhou, X.; Frejat, F.O.A.; Xu, W.; Shan, L. Three New Lactone-Type Diterpenoid Alkaloids from Aconitum rotundifolium Kar. \& Kir. Heterocycles 2017, 94, 1903. [CrossRef]

67. Ahmad, H.; Ahmad, S.; Shah, S.A.A.; Latif, A.; Ali, M.; Khan, F.A.; Tahir, M.N.; Shaheen, F.; Wadood, A.; Ahmad, M. Antioxidant and anticholinesterase potential of diterpenoid alkaloids from Aconitum heterophyllum. Bioorganic Med. Chem. 2017, 25, 3368-3376. [CrossRef]

68. Wang, Y.-J.; Zhang, J.; Zeng, C.-J.; Yao, Z.; Zhang, Y. Three new $\mathrm{C}_{19}$-diterpenoid alkaloids from Aconitum pendulum. Phytochem. Lett. 2011, 4, 166-169. [CrossRef]

69. Shen, Y.; Zuo, A.X.X.; Jiang, Z.Y.; Zhang, X.M.; Wang, H.L.; Chen, J.J. Four New Nor-Diterpenoid Alkaloids from Aconitum brachypodum. Helv. Chim. Acta 2010, 93, 863-869. [CrossRef]

70. Wang, F.; Yue, Z.; Xie, P.; Zhang, L.; Li, Z.; Song, B.; Tang, Z.; Song, X. C 19 -Norditerpenoid Alkaloids from Aconitum szechenyianum and Their Effects on LPS-Activated NO Production. Molecules 2016, 21, 1175. [CrossRef] [PubMed]

71. Li, Y.; Gao, F.; Zhang, J.-F.; Zhou, X.-L. Four New Diterpenoid Alkaloids from the Roots of Aconitum carmichaelii. Chem. Biodivers. 2018, 15, e1800147. [CrossRef] [PubMed]

72. Wang, D.-P.; Lou, H.-Y.; Huang, L.; Hao, X.-J.; Liang, G.-Y.; Yang, Z.-C.; Pan, W.-D. A novel franchetine type norditerpenoid isolated from the roots of Aconitum carmichaeli Debx. with potential analgesic activity and less toxicity. Bioorganic Med. Chem. Lett. 2012, 22, 4444-4446. [CrossRef] [PubMed]

73. Sun, L.-M.; Huang, H.-L.; Li, W.-H.; Nan, Z.-D.; Zhao, G.-X.; Yuan, C.-S. ChemInform Abstract: Alkaloids from Aconitum barbatum var. puberulum. Helv. Chim. Acta 2009, 40, 1126-1133. [CrossRef]

74. Shen, Y.; Zuo, A.-X.; Jiang, Z.-Y.; Zhang, X.-M.; Wang, H.-L.; Chen, J.-J. Hemsleyaconitines F and G, Two Novel C19-Diterpenoid Alkaloids Possessing a Unique Skeleton from Aconitum hemsleyanum. Helv. Chim. Acta 2011, 94, 268-272. [CrossRef]

75. Chen, F.-Z.; Chen, Q.-H.; Wang, F.-P. Diterpenoid Alkaloids from Delphinium yunnanense. Helv. Chim. Acta 2011, 94, 254-260. [CrossRef]

76. Chen, N.-H.; Zhang, Y.-B.; Li, W.; Li, P.; Chen, L.-F.; Li, Y.-L.; Li, G.-Q.; Wang, G.-C. Grandiflodines A and B, two novel diterpenoid alkaloids from Delphinium grandiflorum. RSC Adv. 2017, 7, 24129-24132. [CrossRef]

77. Ma, Y.; Mao, X.Y.; Huang, L.J.; Fan, Y.M.M.; Gu, W.; Yan, C.; Huang, T.; Zhang, J.X.; Yuan, C.M.; Hao, X.J. Diterpene alka-loids and diterpenes from Spiraea japonica and their anti-tobacco mosaic virus activity. Fitoterapia 2016, 109, 8-13. [CrossRef] [PubMed]

78. Nisar, M.; Obaidullah Ahmad, M.; Wadood, N.; Lodhi, M.A.A.; Shaheen, F.; Choudhary, M.I. New diterpenoid alkaloids from Aconitum heterophyllum Wall: Selective butyrylcholinestrase inhibitors. J. Enzyme Inhib. Med. Chem. 2009, 24, 47-51. [CrossRef] [PubMed] 
79. He, Y.Q.; Ma, Z.Y.; Wei, X.M.; Liu, D.J.; Du, B.Z.; Yao, B.H.; Gao, L.M. Honatisine, a Novel Diterpenoid Alkaloid, and Six Known Alkaloids from Delphinium honanense and Their Cytotoxic Activity. Chem. Biodivers. 2011, 8, 2104-2109. [CrossRef] [PubMed]

80. He, Y.Q.; Ma, Z.Y.; Wei, X.M.; Du, B.Z.; Jing, Z.X.; Yao, B.H.; Gao, L.M. Chemical constituents from Delphinium chrysotrichum and their biological activity. Fitoterapia 2010, 81, 929-931. [CrossRef] [PubMed]

81. Liu, X.Y.; Chen, Q.H.; Wang, F.P. Three new $\mathrm{C}_{20}$-diterpenoid alkaloids from Delphinium anthriscifolium var. savatieri. Chin. Chem. Lett. 2009, 20, 698-701. [CrossRef]

82. Shen, Y.; Zuo, A.-X.; Jiang, Z.-Y.; Zhang, X.-M.; Wang, H.-L.; Chen, J.-J. Two New Diterpenoid Alkaloids from Aconitum brachypodum. Bull. Korean Chem. Soc. 2010, 31, 3301-3303. [CrossRef]

83. Wada, K.; Kawahara, N. Diterpenoid and norditerpenoid alkaloids from the roots of Aconitum yesoense var. macroyesoense. Helv. Chim. Acta 2009, 92, 629-637. [CrossRef]

84. Yang, L.-G.; Zhang, Y.-J.; Xie, J.-Y.; Xia, W.-J.; Zhang, H.-Y.; Tang, M.-Y.; Mei, S.-X.; Cui, T.; Wang, J.-K.; Zhu, Z.-Y. Diterpenoid alkaloids from the roots of Aconitum brachypodum Diels. J. Asian Nat. Prod. Res. 2016, 18, 908-912. [CrossRef]

85. Xiong, L.; Peng, C.; Xie, X.-F.; Guo, L.; He, C.-J.; Geng, Z.; Wan, F.; Dai, O.; Zhou, Q.-M. Alkaloids Isolated from the Lateral Root of Aconitum carmichaelii. Molecules 2012, 17, 9939-9946. [CrossRef]

86. Tang, H.; Wen, F.L.; Wang, S.H.; Liu, X.Y.; Chen, D.L.; Wang, F.P. New $\mathrm{C}_{20}$-diterpenoid alkaloids from Aconitum sinomontanum. Chin. Chem. Lett. 2016, 27, 761-763. [CrossRef]

87. Samanbay, A.; Zhao, B.; Aisa, H.A. A new denudatine type $\mathrm{C}_{20}$-diterpenoid alkaloid from Aconitum sinchiangense WT Wang. Nat. Prod. Res. 2018, 32, 2319-2324. [CrossRef]

88. Chen, L.; Shan, L.; Xu, W.; Zhang, J.; Huang, S.; Zhou, X. A new $\mathrm{C}_{20}$-diterpenoid alkaloid from Aconitum soongaricum var. pubescens. Nat. Prod. Res. 2017, 31, 523-528. [CrossRef] [PubMed]

89. Shen, Y.; Zuo, A.X.X.; Jiang, Z.Y.; Zhang, X.M.; Wang, H.L.; Chen, J.J. Two New $\mathrm{C}_{20}$-Diterpenoid Alkaloids from Aconitum carmichaelii. Helv. Chim. Acta 2011, 94, 122-126. [CrossRef]

90. Zhang, Z.-T.; Liu, X.-Y.; Chen, D.-L.; Wang, F.-P. New Diterpenoid Alkaloids from Aconitum liangshanicum. Helv. Chim. Acta 2010, 93, 811-817. [CrossRef]

91. Yin, T.P.; Cai, L.; Xing, Y.; Yu, J.; Li, X.J.J.; Mei, R.F.; Ding, Z.T. Alkaloids with antioxidant activities from Aconitum handelianum. J. Asian Nat. Prod. Res. 2016, 18, 603-610. [CrossRef]

92. Zhao, D.-K.; Shi, X.-Q.; Zhang, L.-M.; Yang, D.-Q.; Guo, H.-C.; Chen, Y.-P.; Shen, Y. Four new diterpenoid alkaloids with antitumor effect from Aconitum nagarum var. heterotrichum. Chin. Chem. Lett. 2017, 28, 358-361. [CrossRef]

93. Chen, F.-Z.; Chen, Q.-H.; Liu, X.-Y.; Wang, F.-P. Diterpenoid Alkaloids from Delphinium tatsienense. Helv. Chim. Acta 2011, 94, 853-858. [CrossRef]

94. Tang, T.X.; Chen, Q.F.; Liu, X.Y.; Jian, X.X.; Wang, F.P. New $\mathrm{C}_{20}$-diterpenoid alkaloids from Aconitum vilmorrianum and structural revision of 2-O-acetylorochrine and orochrine. J. Asian Nat. Prod. Res. 2016, 18, 315-327. [CrossRef] [PubMed]

95. Tang, Q.-F.; Ye, W.-C.; Liu, J.-H.; Yang, C. Three new hetisine-type diterpenoid alkaloids from Aconitum coreanum. Phytochem. Lett. 2012, 5, 397-400. [CrossRef]

96. Lin, C.-Z.; Zhao, Z.-X.; Xie, S.-M.; Mao, J.-H.; Zhu, C.-C.; Li, X.-H.; Bairi, Z.-D.; Kangsa, S.-Q.; Dun, Z.; Xiong, T.-Q.; et al. Diterpenoid alkaloids and flavonoids from Delphinium trichophorum. Phytochemistry 2014, 97, 88-95. [CrossRef] [PubMed]

97. Xing, B.N.; Jin, S.S.; Wang, H.; Tang, Q.F.; Liu, J.H.; Li, R.Y.Y.; Liang, J.Y.; Tang, Y.Q.; Yang, C.H. New diterpenoid alka-loids from Aconitum coreanum and their antiarrhythmic effects on cardiac sodium current. Fitoterapia 2014, 94, 120-126. [CrossRef] [PubMed]

98. Gabbasov, T.M.; Tsyrlina, E.M.; Anatov, D.M.; Spirikhin, L.V.; Yunusov, M.S. Flexiosine, a New C $_{20}$-Diterpene Alkaloid from Roots of Delphinium flexuosum. Chem. Nat. Compd. 2017, 53, 105-108. [CrossRef]

99. Zhang, J.F.; Li, Y.; Gao, F.; Shan, L.H.; Zhou, X.L. Four new $\mathrm{C}_{20}$-diterpenoid alkaloids from Aconitum rotundifolium. J. Asian Nat. Prod. Res. 2019, 21, 716-724. [CrossRef] [PubMed]

100. Zhang, Z.-T.; Liu, X.-Y.; Chen, D.-L.; Wang, F.-P. Three New $\mathrm{C}_{20}$-Diterpenoid Alkaloids from Aconitum tanguticum var. trichocarpum. Nat. Prod. Commun. 2015, 10, 861-862. [CrossRef] [PubMed]

101. He, J.-B.; Luan, J.; Lv, X.-M.; Rui, D.-Y.; Tao, J.; Wang, B.; Niu, Y.-F.; Ju, H.-P. Navicularines A-C: New diterpenoid alkaloids from Aconitum naviculare and their cytotoxic activities. Fitoterapia 2017, 120, 142-145. [CrossRef]

102. Qu, S.-J.; Tan, C.-H.; Liu, Z.-L.; Jiang, S.-H.; Yu, L.; Zhu, D.-Y. Diterpenoid alkaloids from Aconitum tanguticum. Phytochem. Lett. 2011, 4, 144-146. [CrossRef]

103. Liu, X.Y.; Chen, Q.H.; Wang, F.P. New $\mathrm{C}_{20}$-Diterpenoid Alkaloids from Delphinium anthriscifolium var. savatieri. Helv. Chim. Acta 2009, 92, 745-752. [CrossRef]

104. Yu, J.; Yin, T.P.; Wang, J.P.; Mei, R.F.; Cai, L.; Ding, Z.T. A new $\mathrm{C}_{20}$-diterpenoid alkaloid from the lateral roots of Aconitum carmichaeli. Nat. Prod. Res. 2017, 31, 228-232. [CrossRef]

105. Liang, Y.; Wu, J.-L.; Li, X.; Guo, M.-Q.; Leung, E.L.-H.; Zhou, H.; Liu, L.; Li, N. Anti-cancer and anti-inflammatory new vakognavine-type alkaloid from the roots of Aconitum carmichaelii. Tetrahedron Lett. 2016, 57, 5881-5884. [CrossRef]

106. Yu, H.-J.; Liang, T.-T. A New Alkaloid from the Roots of Aconitum carmichaeli Debx. J. Chin. Chem. Soc. 2012, 59, 693-695. [CrossRef]

107. Meng, X.H.; Jiang, Z.B.; Zhu, C.G.; Guo, Q.L.; Xu, C.B.; Shi, J.G. Napelline-type $\mathrm{C}_{20}$-diterpenoid alkaloid iminiums from an aqueous extract of "fu zi": Solvent-/base-/acid-dependent transformation and equilibration between alcohol iminium and aza acetal forms. Chin. Chem. Lett. 2016, 27, 993-1003. [CrossRef] 
108. Levrier, C.; Sadowski, M.C.; Nelson, C.C.; Davis, R.A. Cytotoxic $C_{20}$-Diterpenoid Alkaloids from the Australian Endemic Rainforest Plant Anopterus macleayanus. J. Nat. Prod. 2015, 78, 2908-2916. [CrossRef]

109. Nishanov, A.A.; Tashkhodzhaev, B.; Sultankhodzhaev, M.I.; Ibragimov, B.T.; Yunusov, M.S. Alkaloids of the epigeal part of Aconitum talassicum. Structure of actaline. Chem. Nat. Compd. 1989, 25, 32-36. [CrossRef]

110. Joshi, B.S.; Puar, M.S.; Desai, H.K.; Ross, S.A.; Lu, J.; Pelletier, S.W. The structure of ajabicine, a novel diterpenoid alka-loid from Delphinium ajacis. Tetrahedron Lett. 1993, 34, 1441-1444. [CrossRef]

111. Chen, L.; Shan, L.; Zhang, J.; Xu, W.; Wu, M.; Huang, S.; Zhou, X. Diterpenoid Alkaloids from Aconitum soongaricum var. pubescens. Nat. Prod. Commun. 2015, 10, 2063-2065. [CrossRef] [PubMed]

112. Li, Y.; Smolke, C.D. Engineering biosynthesis of the anticancer alkaloid noscapine in yeast. Nat. Commun. 2016, 7, 12137. [CrossRef] [PubMed]

113. Xie, Y.; Jiang, Z.H.; Zhou, H.; Xu, H.X.; Liu, L. Simultaneous determination of six Aconitum alkaloids in proprietary Chinese medicines by high-performance liquid chromatography. J. Chromatogr. A 2005, 1093, 195-203. [CrossRef] [PubMed]

114. Nyirimigabo, E.; Xu, Y.; Li, Y.; Wang, Y.; Agyemang, K.; Zhang, Y. A review on phytochemistry, pharmacology and toxicology studies of Aconitum. J. Pharm. Pharmacol. 2015, 67, 1-19. [CrossRef] [PubMed]

115. Zong, X.; Yan, X.; Wu, J.-L.; Liu, Z.; Zhou, H.; Li, N.; Liu, L. Potentially Cardiotoxic Diterpenoid Alkaloids from the Roots of Aconitum carmichaelii. J. Nat. Prod. 2019, 82, 980-989. [CrossRef]

116. Tursunkhodzhaeva, F.M.; Dzhakhangirov, F.N.; Salimov, B.T. Diterpenoid alkaloids as antidotes to aconitine-type neu-rotoxin poisoning. Structure-activity relationship. Chem. Nat. Compd. 2016, 52, 849-852. [CrossRef]

117. Yunusov, M.S. Antiarrhythmic agents based on diterpenoid alkaloids. Russ. Chem. Bull. 2011, 60, 633. [CrossRef]

118. Dzhakhangirov, F.N.; Kasymova, K.R.; Sultankhodzhaev, M.N.; Salimov, B.T.; Usmanova, S.K.; Shakirov, R.S. Toxicity and local anesthetic activity of diterpenoid alkaloids. Chem. Nat. Compd. 2007, 43, 581-589. [CrossRef]

119. Chan, T.Y. Aconite poisoning. Clin. Toxicol. 2009, 47, 279-285. [CrossRef] [PubMed]

120. Chen, S.P.L.; Ng, S.W.W.; Poon, W.T.; Lai, C.K.; Ngan, T.M.S.; Tse, M.L.; Chan, T.Y.K.; Chan, A.Y.W.; Mak, T.W.L. Aconite Poisoning over 5 Years. Drug Saf. 2012, 35, 575-587. [CrossRef] [PubMed]

121. Li, H.; Liu, L.; Zhu, S.; Liu, Q. Case reports of aconite poisoning in mainland China from 2004 to 2015: A retrospective analysis. J. Forensic Leg. Med. 2016, 42, 68-73. [CrossRef] [PubMed]

122. Ramawat, K.G.; Mérillon, J.M. (Eds.) Natural Products: Phytochemistry, Botany and Metabolism of Alkaloids, Phenolics and Terpenes; Springer: Heidelberg, Germany, 2013; pp. 1541-2662.

123. Daum, G.; Lees, N.D.; Bard, M.; Dickson, R. Biochemistry, cell biology and molecular biology of lipids of Saccharomyces cerevisiae. Yeast 1998, 14, 1471-1510. [CrossRef]

124. Sun, G.-B.; Sun, H.; Meng, X.-B.; Hu, J.; Zhang, Q.; Liu, B.; Wang, M.; Xu, H.-B.; Sun, X.-B. Aconitine-induced Ca ${ }^{2+}$ overload $^{-}$ causes arrhythmia and triggers apoptosis through p38 MAPK signaling pathway in rats. Toxicol. Appl. Pharmacol. 2014, 279, 8-22. [CrossRef]

125. Yang, M.; Ji, X.; Zuo, Z. Relationships between the toxicities of Radix Aconiti Lateralis Preparata (Fuzi) and the toxicoki-netics of its main diester-diterpenoid alkaloids. Toxins 2018, 10, 391. [CrossRef]

126. Ye, Q.; Liu, H.; Fang, C.; Liu, Y.; Liu, X.; Liu, J.; Zhang, C.; Zhang, T.; Peng, C.; Guo, L. Cardiotoxicity evaluation and comparison of diterpene alkaloids on zebrafish. Drug Chem. Toxicol. 2021, 44, 294-301. [CrossRef]

127. Chen, L.; Yang, J.; Davey, A.K.; Chen, Y.X.; Wang, J.P.; Liu, X.Q. Effects of diammonium glycyrrhizinate on the phar-macokinetics of aconitine in rats and the potential mechanism. Xenobiotica 2009, 39, 955-963. [CrossRef]

128. Ye, L.; Yang, X.; Yang, Z.; Gao, S.; Yin, T.; Liu, W.; Wang, F.; Hu, M.; Liu, Z. The role of efflux transporters on the transport of highly toxic aconitine, mesaconitine, hypaconitine, and their hydrolysates, as determined in cultured Caco-2 and transfected MDCKII cells. Toxicol. Lett. 2013, 216, 86-99. [CrossRef]

129. Pereira, F. Polypharmacology of Aconitum and Delphinium sp. Diterpene Alkaloids: Antiarrhythmic, Analgesic and An-tiInflammatory Effects. Mini-Rev. Org. Chem. 2017, 14, 304-310. [CrossRef]

130. Lai, M.C.; Liu, I.M.; Liou, S.S.; Chang, Y.S. Mesaconitine plays the major role in the antinociceptive and an-ti-inflammatory activities of radix Aconiti carmichaeli (Chuan wu). J. Food Drug Anal. 2011, 19, 362-368.

131. Hai, Q.S.; Ma, X.X.X.; Yang, Y.Q.; Yang, Z.Y. Comparation of Three Kinds of Diterpenoid Alkaloid from Aconitum bulleyanum Diels in Related Pharmacodynamics and Toxicity. J. Kunming Med. Univ. 2017, 1, 18-22.

132. Nesterova, Y.V.; Povet'Yeva, T.N.; Suslov, N.I.; Zyuz'Kov, G.N.; Pushkarskii, S.V.; Aksinenko, S.G.; Schultz, E.E.; Kravtsova, S.S.; Krapivin, A.V. Analgesic Activity of Diterpene Alkaloids from Aconitum baikalensis. Bull. Exp. Biol. Med. 2014, 157, 488-491. [CrossRef] [PubMed]

133. Huang, Q.; Sun, M.-L.; Chen, Y.; Li, X.-Y.; Wang, Y.-X. Concurrent bullatine A enhances morphine antinociception and inhibits morphine antinociceptive tolerance by indirect activation of spinal k-opioid receptors. J. Ethnopharmacol. 2017, 196, 151-159. [CrossRef] [PubMed]

134. Wang, J.-L.; Shen, X.-L.; Chen, Q.-H.; Qi, G.; Wang, W.; Wang, F.-P. Structure-Analgesic Activity Relationship Studies on the C 18 and $\mathrm{C}_{19}$-Diterpenoid Alkaloids. Chem. Pharm. Bull. 2009, 57, 801-807. [CrossRef]

135. Fan, X.; Yin, S.-S.; Li, X.-J.; Yang, K.; Xu, L.; Lan, K. Hydroxylation Metabolisms of Crassicauline A in Rats Under Toxic Dose. Eur. J. Drug Metab. Pharmacokinet. 2017, 42, 857-869. [CrossRef] 
136. Khan, H.; Nabavi, S.M.; Sureda, A.; Mehterov, N.; Gulei, D.; Berindan-Neagoe, I.; Taniguchi, H.; Atanasov, A.G. Therapeutic potential of songorine, a diterpenoid alkaloid of the genus Aconitum. Eur. J. Med. Chem. 2018, 153, 29-33. [CrossRef]

137. Sun, M.-L.; Ao, J.-P.; Wang, Y.-R.; Huang, Q.; Li, T.-F.; Li, X.-Y.; Wang, Y.-X. Lappaconitine, a C 18 -diterpenoid alkaloid, exhibits antihypersensitivity in chronic pain through stimulation of spinal dynorphin A expression. Psychopharmacology 2018, 235, 2559-2571. [CrossRef]

138. Gutser, U.T.; Friese, J.; Heubach, J.F.; Matthiesen, T.; Selve, N.; Wilffert, B.; Gleitz, J. Mode of antinociceptive and toxic action of alkaloids of Aconitum spec. Naunyn-Schmiedeberg's Arch. Pharmacol. 1997, 357, 39-48. [CrossRef]

139. Sun, W.; Zhang, S.; Wang, H.; Wang, Y. Synthesis, characterisation and antinociceptive properties of the lappaconitine salts. Med. Chem. Res. 2015, 24, 3474-3482.

140. Li, S.; Zhang, H.; Zhu, X.; Zhao, Z.; Zhang, T. Research progress on new preparations of lappaconitine. Drugs Clin. 2014, 29, 818-823.

141. Shang, X.-Y.; Li, S.; Wang, S.-J.; Yang, Y.-C.; Shi, J.-G. Chemical constituents of Bauhinia aurea. J. Asian Nat. Prod. Res. 2012, 14, 966-972. [CrossRef]

142. Jiang, B.; Lin, S.; Zhu, C.; Wang, S.; Wang, Y.; Chen, M.; Zhang, J.; Hu, J.; Chen, N.; Yang, Y.; et al. Diterpenoid Alkaloids from the Lateral Root of Aconitum carmichaelii. J. Nat. Prod. 2012, 75, 1145-1159. [CrossRef] [PubMed]

143. Yin, T.; Hu, X.; Mei, R.; Shu, Y.; Gan, D.; Cai, L.; Ding, Z. Four new diterpenoid alkaloids with anti-inflammatory activities from Aconitum taronense Fletcher et Lauener. Phytochem. Lett. 2018, 25, 152-155. [CrossRef]

144. Wangchuk, P.; Navarro, S.; Shepherd, C.; Keller, P.A.; Pyne, S.G.; Loukas, A. Diterpenoid alkaloids of Aconitum laciniatum and mitigation of inflammation by 14-O-acetylneoline in a murine model of ulcerative colitis. Sci. Rep. 2015, 5, 12845. [CrossRef] [PubMed]

145. Li, X.; Li, N.; Sui, Z.; Bi, K.; Li, Z. An investigation on the quantitative structure-activity relationships of the anti-inflammatory activity of diterpenoid alkaloids. Molecules 2017, 22, 363. [CrossRef] [PubMed]

146. Nesterova, Y.V.; Povetieva, T.N.; Suslov, N.I.; Zyuz'Kov, G.N.; Aksinenko, S.G.; Pushkarskii, S.V.; Krapivin, A.V. Anti-inflammatory activity of diterpene alkaloids from Aconitum baikalense. Bull. Exp. Biol. Med. 2014, 156, 665-668. [CrossRef] [PubMed]

147. Yin, T.-P.; Cai, L.; Zhou, H.; Zhu, X.-F.; Chen, Y.; Ding, Z.-T. A new C19-diterpenoid alkaloid from the roots of Aconitum duclouxii. Nat. Prod. Res. 2014, 28, 1649-1654. [CrossRef]

148. Liang, X.; Gao, Y.; Luan, S. Two decades of advances in diterpenoid alkaloids with cytotoxicity activities. RSC Adv. 2018, 8 , 23937-23946. [CrossRef]

149. Wada, K.; Ohkoshi, E.; Morris-Natschke, S.L.; Bastow, K.F.; Lee, K.H. Cytotoxic esterified diterpenoid alkaloid deriva-tives with increased selectivity against a drug-resistant cancer cell line. Bioorg. Med. Chem. Lett. 2012, 22, 249-252. [CrossRef] [PubMed]

150. Guo, Z.-J.; Xu, Y.; Zhang, H.; Li, M.-Y.; Xi, K. New alkaloids from Aconitum taipaicum and their cytotoxic activities. Nat. Prod. Res. 2013, 28, 164-168. [CrossRef] [PubMed]

151. Gao, F.; Li, Y.-Y.; Wang, D.; Huang, X.; Liu, Q. Diterpenoid Alkaloids from the Chinese Traditional Herbal "Fuzi" and Their Cytotoxic Activity. Molecules 2012, 17, 5187-5194. [CrossRef]

152. Zhang, H.; Wu, Q.; Li, W.; Sun, S.; Zhang, W.; Zhu, Z.; Zhang, G.; Chai, Y. Absorption and metabolism of three mo-noesterditerpenoid alkaloids in Aconitum carmichaeli after oral administration to rats by HPLC-MS. J. Ethnopharmacol. 2014, 154, 645-652. [CrossRef]

153. Zhang, H.; Guo, Z.; Han, L.; You, X.; Xu, Y. The antitumor effect and mechanism of taipeinine A, a new $\mathrm{C}_{19}$-diterpenoid alkaloid from Aconitum taipeicum, on the HepG2 human hepatocellular carcinoma cell line. J. B. U. ON. Off. J. Balk. Union Oncol. 2014, 19, 705-712.

154. Ren, M.-Y.; Yu, Q.-T.; Shi, C.-Y.; Luo, J.-B. Anticancer Activities of $\mathrm{C}_{18^{-}}, \mathrm{C}_{19^{-}}, \mathrm{C}_{20^{-}}$, and Bis-Diterpenoid Alkaloids Derived from Genus Aconitum. Molecules 2017, 22, 267. [CrossRef]

155. Lin, L.; Chen, D.-L.; Liu, X.-Y.; Chen, Q.-H.; Wang, F.-P.; Yang, C.-Y. Bis-Diterpenoid Alkaloids from Aconitum tanguticum Var. trichocarpum. Nat. Prod. Commun. 2009, 4, 897-901. [CrossRef]

156. Zhang, Z.T.; Chen, D.L.; Chen, Q.H.; Wang, F.P. Bis-Diterpenoid Alkaloids from Aconitum tanguticum var. trichocarpum. Helv. Chim. Acta 2013, 96, 710-718. [CrossRef]

157. Guo, Q.; Xia, H.; Wu, Y.; Shao, S.; Xu, C.; Zhang, T.; Shi, J. Structure, property, biogenesis, and activity of diterpenoid alkaloids containing a sulfonic acid group from Aconitum carmichaelii. Acta. Pharm. Sin. B. 2020, 10, 1954-1965. [CrossRef]

158. Duan, X.Y.; Zhao, D.K.; Shen, Y. Two new bis- $\mathrm{C}_{20}$-diterpenoid alkaloids with anti-inflammation activity from Aconitum bulleyanum. J. Asian Nat. Prod. Res. 2019, 21, 323-330. [CrossRef]

159. Cragg, G.M.; Kingston, D.G.; Newman, D.J. Anticancer Agents from Natural Products; Taylor \& Francis: Boca Raton, FL, USA; Volume 23, pp. 676-686.

160. Rho, J.R.; Oh, M.S.; Jang, K.H.; Cho, K.W.; Shin, J. New xenicane diterpenoids from the gorgonian Acalycigorgia inermis. J. Nat. Prod. 2001, 64, 540-543. [CrossRef]

161. Kwon, H.J.; Kim, J.H.; Jung, H.J.; Kwon, Y.G.; Kim, M.Y.; Rho, J.R.; Shin, J.H. Antiangiogenic Activity of Acalycixenolide E, a Novel Marine Natural Product from Acallycigorgia inermis. J. Microbiol. Biotechnol. 2001, 11, 656-662.

162. Bishara, A.; Rudi, A.; Goldberg, I.; Benayahu, Y.; Kashman, Y. Novaxenicins A-D and xeniolides I-K, seven new diterpenes from the soft coral Xenia novaebrittanniae. Tetrahedron 2006, 62, 12092-12097. [CrossRef] 
163. El-Gamal, A.A.; Chiang, C.Y.; Huang, S.H.; Wang, S.K.; Duh, C.Y. Xenia Diterpenoids from the Formosan Soft Coral Xenia blumi. J. Nat. Prod. 2005, 68, 1336-1340. [CrossRef]

164. Blunt, J.W.; Copp, B.; Munro, M.; Northcote, P.T. Marine natural products. Nat. Prod. Rep. 2004, 21, 1-49. [CrossRef] [PubMed]

165. Miyaoka, H.; Mitome, H.; Nakano, M.; Yamada, Y. Xeniaoxolane: A New Xenicane-type Diterpenoid from the Okinawan Soft Coral, Xenia sp.; Absolute Configurations of Xeniaoxolane, Xeniolide-A and Xenialactol. Tetrahedron 2000, 56, 7737-7740. [CrossRef]

166. Rho, J.R.; Lee, H.S.; Seo, Y.; Cho, K.W.; Shin, J. New Xenicane Diterpenoids from the Gorgonian Acalycigorgia inermis. J. Nat. Prod. 2000, 63, 254-257. [CrossRef] [PubMed]

167. Anta, C.; González, N.; Santafé, G.; Rodríguez, J.; Jiménez, C. New Xenia diterpenoids from the Indonesian soft coral Xenia sp. J. Nat. Prod. 2002, 65, 766-768. [CrossRef]

168. Iwasaki, J.; Ito, H.; Aoyagi, M.; Sato, Y.; Iguchi, K. Briarane-Type Diterpenoids from the Okinawan Soft Coral Pachy-clavularia violacea. J. Nat. Prod. 2006, 69, 2-6. [CrossRef]

169. Sung, P.-J.; Sheu, J.-H.; Xu, J.-P. Survey of Briarane-Type Diterpenoids of Marine Origin. Heterocycles 2002, 57, 535. [CrossRef]

170. Shimomura, M.; Miyaoka, H.; Yamada, Y. Absolute configuration of marine diterpenoid kalihinol A. Tetrahedron Lett. 1999, 40, 8015-8017. [CrossRef]

171. Patra, A.; Chang, C.W.J.; Scheuer, P.J.; Van Duyne, G.D.; Matsumoto, G.K.; Clardy, J. An unprecedented triisocyano diterpenoid antibiotic from a sponge. J. Am. Chem. Soc. 1984, 106, 7981-7983. [CrossRef]

172. Chang, C.W.; Patra, A.; Baker, J.A.; Scheuer, P.J. Kalihinols, multifunctional diterpenoid antibiotics from marine sponges Acanthella spp. J. Am. Chem. Soc. 1987, 109, 6119-6123. [CrossRef]

173. Omar, S.; Albert, C.; Fanni, T.; Crews, P. Polyfunctional diterpene isonitriles from marine sponge Acanthella carvenosa. J. Org. Chem. 1988, 53, 5971-5972. [CrossRef]

174. Fusetani, N.; Yasumuro, K.; Kawai, H.; Natori, T.; Brinen, L.; Clardy, J. Kalihinene and isokalihinol B, cytotoxic diterpene isonitriles from the marine sponge Acanthella klethra. Tetrahedron Lett. 1990, 31, 3599-3602. [CrossRef]

175. Alvi, K.A.; Tenenbaum, L.; Crews, P. Anthelmintic Polyfunctional Nitrogen-Containing Terpenoids from Marine Sponges. J. Nat. Prod. 1991, 54, 71-78. [CrossRef]

176. Trimurtulu, G.; Faulkner, D.J. Six New Diterpene Isonitriles from the Sponge Acanthella cavernosa. J. Nat. Prod. 1994, 57, 501-506. [CrossRef]

177. Braekman, J.C.; Daloze, D.; Gregoire, F.; Popov, S.; Van Soest, R. Two new Kalihinenes from the Marine Sponge Acanthella cavernosa. Bull. Sociétés Chim. Belg. 2010, 103, 187-191. [CrossRef]

178. Laurent, D.; Pietra, F. Antiplasmodial marine natural products in the perspective of current chemotherapy and prevention of malaria. A review. Mar. Biotechnol. 2006, 8, 433-447. [CrossRef]

179. Okino, T.; Yoshimura, E.; Hirota, H.; Fusetani, N. Antifouling kalihinenes from the marine sponge Acanthella cavernosa. Tetrahedron Lett. 1995, 36, 8637-8640. [CrossRef]

180. Hirota, H.; Tomono, Y.; Fusetani, N. Terpenoids with antifouling activity against barnacle larvae from the marine sponge Acanthella cavernosa. Tetrahedron 1996, 52, 2359-2368. [CrossRef]

181. Fusetani, N. Antifouling activity of isocyanoterpenoids and related compounds isolated from a marine sponge and nudi-branchs. J. Nat. Toxins 1996, 5, 249-259.

182. Okino, T.; Yoshimura, E.; Hirota, H.; Fusetani, N. New antifouling kalihipyrans from the marine sponge Acanthella cavernosa. J. Nat. Prod. 1996, 59, 1081-1083. [CrossRef]

183. Wolf, D.; Schmitz, F.J. New Diterpene Isonitriles from the Sponge Phakellia pulcherrima. J. Nat. Prod. 1998, 61, 1524-1527. [CrossRef] [PubMed]

184. Miyaoka, H.; Shimomura, M.; Kimura, H.; Yamada, Y.; Kim, H.-S.; Yusuke, W. Antimalarial activity of kalihinol A and new relative diterpenoids from the Okinawan sponge, Acanthella sp. Tetrahedron 1998, 54, 13467-13474. [CrossRef]

185. Mori, K.; Iguchi, K.; Yamada, N.; Yamada, Y.; Inouye, Y. Stolonidiol, a new marine diterpenoid with a strong cytotoxic activity from the Japanese soft coral. Tetrahedron Lett. 1987, 28, 5673-5676. [CrossRef]

186. Yabe, T.; Yamada, H.; Shimomura, M.; Miyaoka, H.; Yamada, Y. Induction of Choline Acetyltransferase Activity in Cholinergic Neurons by Stolonidiol: Structure-Activity Relationship. J. Nat. Prod. 2000, 63, 433-435. [CrossRef]

187. Faulkner, D.J. Marine natural products. Nat. Prod. Rep. 2001, 18, 1R-49R. [CrossRef]

188. Rodríguez, A.D.; González, E.; Ramírez, C. The structural chemistry, reactivity, and total synthesis of dolabellane diterpenes. Tetrahedron 1998, 54, 11683-11729. [CrossRef]

189. Chang, C.W.; Patra, A.; Roll, D.M.; Scheuer, P.J.; Matsumoto, G.K.; Clardy, J. Kalihinol-A, a highly functionalised diisocyano diterpenoid antibiotic from a sponge. J. Am. Chem. Soc. 1984, 106, 4644-4646. [CrossRef]

190. Sipkema, D.; Franssen, M.C.R.; Osinga, R.; Tramper, J.; Wijffels, R.H. Marine Sponges as Pharmacy. Mar. Biotechnol. 2005, 7, 142-162. [CrossRef] [PubMed]

191. Garson, M.J.; Simpson, J. Marine isocyanides and related natural products; structure, biosynthesis and ecology. Nat. Prod. Rep. 2004, 21, 164-179. [CrossRef] [PubMed]

192. White, R.D.; Wood, J.L. Progress toward the total synthesis of kalihinane diterpenoids. Org. Lett. 2001, 3, 1825-1827. [CrossRef] [PubMed] 